\title{
Melting carbonated epidote eclogites: carbonatites from subducting slabs
}

\author{
Stefano Poli
}

\begin{abstract}
Current knowledge on the solidus temperature for carbonated eclogites suggests that carbonatitic liquids should not form from a subducted oceanic lithosphere at sub-arc depth. However, the oceanic crust includes a range of gabbroic rocks, altered on rifts and transforms, with large amounts of anorthite-rich plagioclase forming epidote on metamorphism. Epidote disappearance with pressure depends on the normative anorthite content of the bulk composition; we therefore expect that altered gabbros might display a much wider pressure range where epidote persists, potentially affecting the solidus relationships. A set of experimental data up to $4.6 \mathrm{GPa}$, and $1000{ }^{\circ} \mathrm{C}$, including new syntheses on mafic eclogites with $36.8 \%$ normative anorthite, is discussed to unravel the effect of variable bulk and volatile compositions in model eclogites, enriched in the normative anorthite component $\left(A n_{37}\right.$ and $\left.A n_{45}\right)$. Experiments are performed in piston cylinder and multianvil machines. Garnet, clinopyroxene, and coesite form in all syntheses. Lawsonite was found to persist at $3.7 \mathrm{GPa}, 750{ }^{\circ} \mathrm{C}$, with both dolomite and magnesite; at $3.8 \mathrm{GPa}, 775-800{ }^{\circ} \mathrm{C}$, fluid-saturated conditions, epidote coexists with kyanite, dolomite, and magnesite. The anhydrous assemblage garnet, omphacite, aragonite, and kyanite is found at $4.2 \mathrm{GPa}, 850{ }^{\circ} \mathrm{C}$. At $900{ }^{\circ} \mathrm{C}$, a silicate glass of granitoid composition, a carbonatitic precipitate, and Na-carbonate are observed. Precipitates are interpreted as evidence of hydrous carbonatitic liquids at run conditions; these liquids produced are richer in $\mathrm{Ca}$ compared to experimental carbonatites from anhydrous experiments, consistently with the dramatic role of $\mathrm{H}_{2} \mathrm{O}$ in depressing the solidus temperature for $\mathrm{CaCO}_{3}$. The fluid-absent melting of the assemblage epidote + dolomite, enlarged in its pressure stability for An-rich gabbros, is expected to promote the generation of carbonatitic liquids. The subsolidus breakdown of epidote in the presence of carbonates at depths exceeding $120 \mathrm{~km}$ provides a major source of $\mathrm{C}-\mathrm{O}-\mathrm{H}$ volatiles at sub-arc depth. In warm subduction zones, the possibility of extracting carbonatitic liquids from a variety of gabbroic rocks and epidosites offers new scenarios on the metasomatic processes in the lithospheric wedge of subduction zones and a new mechanism for recycling carbon.
\end{abstract}

Keywords: Eclogite, Carbonatite, Carbon cycle, Kyanite, Epidote, Calcite, Subduction

\section{Introduction}

Epidote is a hydroxylated Ca-Al-silicate commonly observed in a variety of high-pressure rocks, from basaltic eclogites, to metagabbros and rodingites of the metamorphosed oceanic crust, then to intermediate rock compositions representative of slices of the continental crust involved in high-pressure processes at subduction zones. The stability field of the epidote zoisite has been thoroughly explored experimentally in the model system $\mathrm{CaO}-\mathrm{Al}_{2} \mathrm{O}_{3}-\mathrm{SiO}_{2}-\mathrm{H}_{2} \mathrm{O}(\mathrm{CASH}$, Boettcher 1970; Poli and Schmidt, 1998 and

Correspondence: stefano.poli@unimi.it

Dipartimento di Scienze della Terra, Università degli Studi di Milano, Via Botticelli 23, Milan 20133, Italy a fluid-absent melting reaction at approximately $1200{ }^{\circ} \mathrm{C}$, although experimental data at high temperature are missing above $2.6 \mathrm{GPa}$. As a result of such an extended stability in pressure-temperature-composition space, epidote is found both in metamorphic and magmatic rocks (Poli and Schmidt 2004; Schmidt and Poli, 2004).

references therein). High-pressure phase relationships at the boundaries of zoisite stability field are characterized by reactions involving lawsonite at low temperature, by the subsolidus dehydration reaction:

$$
\text { zoisite }=\text { grossular }+ \text { kyanite }+ \text { coesite }+ \text { vapor }
$$


The melting of zoisite at high pressure (Fig. 1), i.e., above the stability of anorthite $+\mathrm{H}_{2} \mathrm{O}$, can be described by three model reactions of relevance in a variety of relatively Ca-rich bulk compositions:

$$
\text { zoisite }+ \text { kyanite }+ \text { quartz/coesite }+ \text { vapor }=\text { liquid }
$$

zoisite + quartz $/$ coesite $=$ grossular + kyanite + liquid

$$
\text { zoisite }=\text { grossular }+ \text { kyanite }+ \text { corundum }+ \text { liquid }
$$

or, eventually,

$$
\text { zoisite }=\text { grossular }+ \text { kyanite }+ \text { liquid }
$$

if the liquid composition degenerates on the plane kyanite-grossular-vapor (see Figure $2 \mathrm{~b}$ in Schmidt and Poli, 2004). Eutectic occurs on reaction (2), potentially accounting for wet melting of an eclogite beyond the stability field of amphibole.

The extent of pressure stability of epidote in eclogites has been proposed to be a function of the normative anorthite content $(A n)$ of the bulk composition of the system of interest. Zoisite was found in eclogite assemblages in a MOR basalt composition with normative anorthite content $A n=31 \%$ to $3 \mathrm{GPa}$ by Poli et al. (2009) and up to at least $4 \mathrm{GPa}, 900{ }^{\circ} \mathrm{C}$ in a plagioclaserich gabbro, $A n=71 \%$ by Wittenberg et al. (2003). As the wet solidus for MOR basalts approaches such conditions (Fig. 1), epidote is expected to affect melting of mafic eclogites at pressures largely exceeding the amphibole stability field, therefore down to sub-arc depths. The role and pressure effect of $\mathrm{Fe}^{3+}$ is unexplored and may further expand epidote stability if $\mathrm{Fe}^{3+}$ preferentially partitions in epidote with respect to garnet.

The abundance of epidote in the subsolidus is again governed by the abundance of anorthite component in plagioclase hydrated at low pressure following the reaction:

$$
4 \text { anorthite }+1 \mathrm{H}_{2} \mathrm{O}=2 \text { zoisite }+1 \text { kyanite }+1 \text { quartz }
$$

The large majority of experimental studies dealt with phase transformations in eclogites derived from the socalled "altered oceanic crust"; these studies have focused on a very limited range of bulk compositions (Fig. 2), based on minor chemical variations of a mid-ocean ridge basalt (other than for volatile components added by hydrothermal processes). $\mathrm{Mg}$ numbers $(100 \times \mathrm{Mg} /(\mathrm{Mg}+$ $\left.\mathrm{Fe}^{2+}\right)$ ) range from 47 in Forneris and Holloway (2003) to a maximum of 64 in starting material SLEC1 used by Dasgupta et al. (2004); normative $A n$ range from 23 in SLEC1 to 31 in bulk OTB used by Poli et al. (2009). However, the mafic oceanic crust includes sequences of gabbros, olivine gabbros, and troctolites several kilometers in thickness. Plutonic rocks of the oceanic crust have been

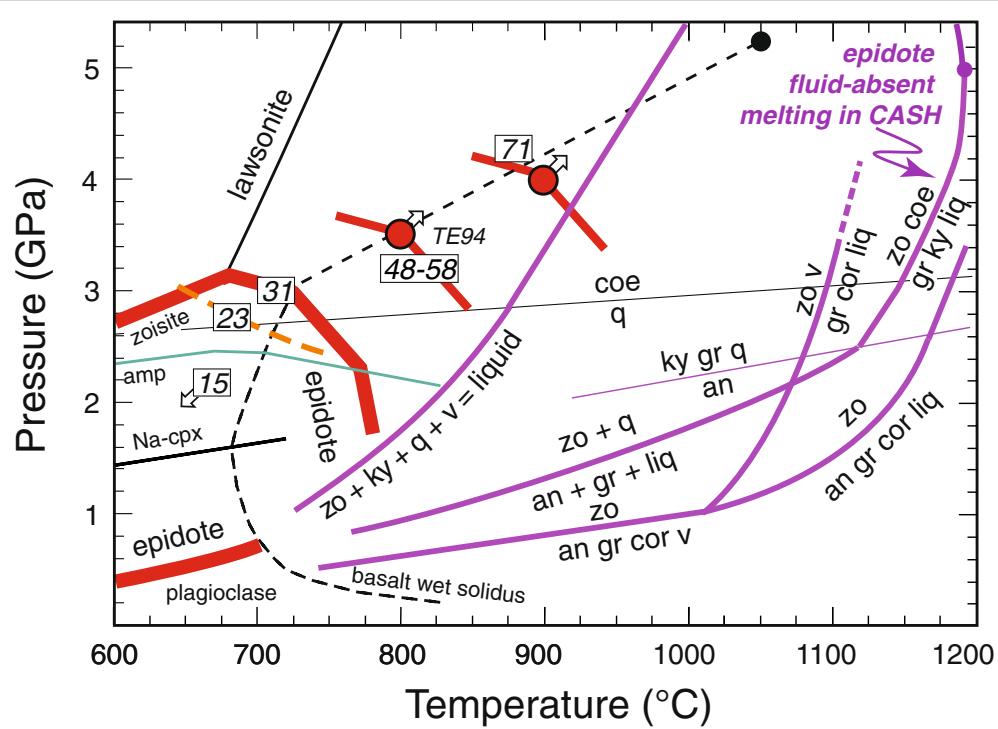

Fig. 1 The stability field of zoisite and epidote. Reaction lines in violet are for zoisite relations in the model system $\mathrm{CaO}-\mathrm{Al}_{2} \mathrm{O}_{3}-\mathrm{SiO}_{2}-\mathrm{H}_{2} \mathrm{O}(\mathrm{CASH})$. Boundaries in red represent schematically the displacement of the maximum extent of epidote in mafic and intermediate bulk compositions as a function of CIPW normative anorthite content, An. Bold numbers indicate anorthite contents in weight percent from studies that synthesized epidote (circles; An =48-58: Thompson and Ellis 1994; An =71: Wittenberg et al. 2003) or defined an epidote-out reaction (An=31: Poli and Schmidt 1995; Schmidt and Poli 1998; An=23: Forneris and Holloway 2003, broken bold line). Experiments performed on a Mg-rich andesite, with An =15 (Poli and Schmidt 1995), did not result in the presence of epidote, pointing to a low-pressure stability of epidote in such composition. Dashed line represents the wet solidus after Kessel et al. (2005), black dot stands for the second critical endpoint 


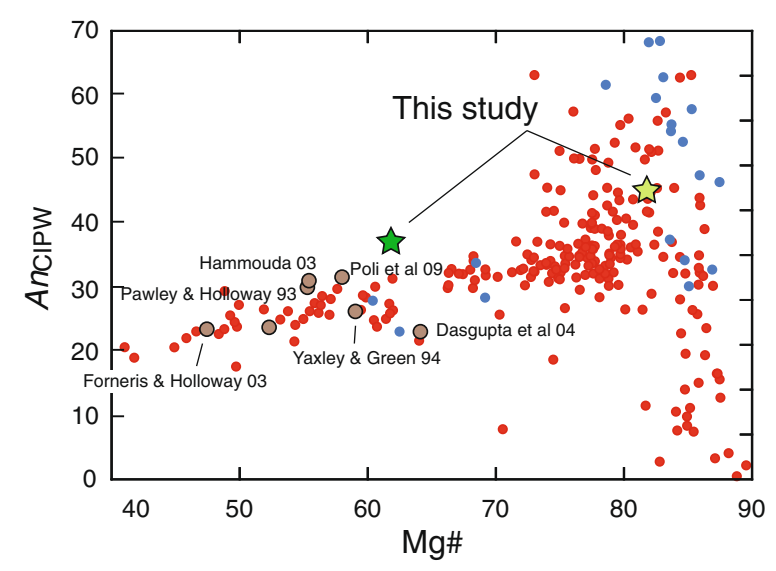

Fig. 2 The diversity of plutonic rocks in the oceanic crust. Normative CIPW anorthite content (An) vs. Mg\# values, $100 \times \mathrm{Mg} /(\mathrm{Mg}+\mathrm{Fe})$, of starting materials used in previous experimental studies (brown circles) compared to variability of compositions for gabbroic rocks sampled in modern oceanic crusts. Red dots are from Godard et al. (2009) and blue dots from Perk et al. (2007). Stars are the two bulk compositions adopted in this study

sampled along the East Pacific Rise, at the Pito Deep (Perk et al., 2007), on the Mid-Atlantic Ridge, Atlantis Massif (Godard et al., 2009), and at the Southwest Indian Ridge (Meyer et al., 1989). Remnants of such oceanic cumulate rocks are then recognizable in high-pressure terrains, e.g., in the Alps (Bucher and Grapes, 2009, Lagabrielle et al., 2015) testifying to their relevance in orogenic processes. Cumulates are characterized by variable amount of olivine and plagioclase, the latter usually exceeding $50 \%$ in volume, often up to $70-80 \%$ in volume. As such cumulates are derived from primitive liquids, the fraction of anorthite component is high, e.g., approximately $0.7-0.8$ for more than $700 \mathrm{~m}$ in the section of the East Pacific Rise (Perk et al., 2007). The mineralogical features of gabbros and troctolites result in a strong compositional variability (Fig. 2), ranging from "MORB" to cumulate compositions

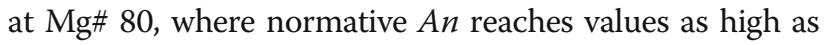
70. Hydrothermal alteration and prograde metamorphism of these compositions will therefore produce phase assemblages enriched in epidote.

The limited set of plutonic rocks sampled in oceans hampers a correct assessment of the alteration pattern of the lower crustal sequences. Bach et al. (2001) presented a detailed reconstruction of chemical exchanges between seawater and oceanic lithosphere in the ODP Hole 735B which sampled gabbros down to $1500 \mathrm{~m}$ below seafloor at the SW Indian Ridge. A complex and multistage low-temperature $\left(<250{ }^{\circ} \mathrm{C}\right)$ alteration history, typically confined to fractured regions, is responsible for the precipitation of secondary smectite-chlorite mixedlayer minerals, chlorite, calcite, zeolite, sulfide, and Fe-oxyhydroxide, resulting in percent level of both
$\mathrm{H}_{2} \mathrm{O}$ and $\mathrm{CO}_{2}$ added. It is worth noting that carbonation appears to be a slow process, active on timescales in the order of tens of million years (Alt and Teagle, 1999). Furthermore, fluid-rock interaction may act at much greater depths, e.g., along active faults at the outer rise outboard of trenches (Faccenda, 2014).

The devolatilization history of altered gabbros on subduction is characterized by the progressive disappearance of the hydrous phases lawsonite, chlorite, paragonite, amphibole, and eventually talc. Melting within the pressure stability field of amphibole is unlikely at subduction zones, unless unusually "hot" regimes occur (e.g., early subduction of young oceanic crust). At pressures higher than 2.5-2.8 GPa, i.e., above amphibole breakdown in mafic eclogites (Poli et al., 2009), epidote is the only major $\mathrm{H}_{2} \mathrm{O}$ reservoir of the subducted oceanic crust, for temperatures exceeding lawsonite stability (Fig. 1). When $\mathrm{CO}_{2}$ is added by low-pressure fluidrock interactions, the carbonates potentially stable at P-T conditions beyond amphibole stability field are magnesite-siderite solid solution, dolomite-ankerite$\mathrm{Mg}$-calcite solution, and the high-pressure polymorph of $\mathrm{CaCO}_{3}$, aragonite.

The wet solidus for MOR basalts (Kessel et al., 2005) is located approximately $100^{\circ}$ lower than eutectic reaction (2) in the model system $\mathrm{CASH}$, at $2.5 \mathrm{GPa}$, and, because of a lower $\mathrm{dP} / \mathrm{dT}$ slope, it converges and intersects reaction (2) at approximately 4.5 $\mathrm{GPa}$. We therefore expect that epidote and ternary carbonates will play a fundamental role on reactions on the solidus at variable volatile component abundances, for pressure between 3 and $5 \mathrm{GPa}$, i.e., for depths of the slab typical for the subarc at subduction zones. The goal of this exploratory survey is to constrain the nature of liquids formed upon melting of zoisite-bearing carbonated eclogites. This work also builds on a summary of experimental results presented in Poli (2015).

\section{Methods/Experimental \\ Bulk compositions and starting materials}

The composition of an olivine gabbro from the Southwest Indian Ridge (sample 59-3, Table 1, Meyer et al., 1989) was used as a representative composition for most experiments in this work. The modal proportions of major constituents in the original gabbro 59-3 are $63 \%$ plagioclase and $33 \%$ clinopyroxene. This bulk composition has a normative $A n_{\mathrm{CIPW}}=44.9, \quad \mathrm{Mg} \#=81.8$, and $\mathrm{Ca} /(\mathrm{Ca}+\mathrm{Mg}+\mathrm{Fe})=0.497$. Additionally, a first set of experiments was performed on an altered basalt compositions (sample 80-3, Alt and Emmermann, 1985), with $A n_{\mathrm{CIPW}}=36.8, \mathrm{Mg} \#=61.8$, and $\mathrm{Ca} /(\mathrm{Ca}+$ $\mathrm{Mg}+\mathrm{Fe})=0.449$. These two representative compositions of the variability of the oceanic crust compared to an average MORB or altered MORB are displaced 
Table 1 Bulk composition and CIPW norm of representative oceanic gabbros and of starting material used in this study and in previous experimental studies

\begin{tabular}{|c|c|c|c|c|c|c|c|c|c|c|c|c|c|}
\hline & 59-3 & $80-3$ & A1-2 & 593-ccb & 59-3-ccb-CA & 59-3-ccb-CB & OTB & SLEC1 & SLEC3 & OTBC & GA1cc & EC1 & Witt \\
\hline $\mathrm{SiO}_{2}$ & 49.26 & 48.10 & 38.16 & 43.84 & 35.13 & 33.83 & 52.38 & 41.21 & 41.69 & 47.23 & 45.32 & 30.11 & 45.60 \\
\hline $\mathrm{TiO}_{2}$ & 0.06 & 0.84 & 0.20 & - & 0.04 & 0.04 & 0.00 & 2.16 & 2.18 & 0.00 & 1.34 & 0.00 & 0.09 \\
\hline $\mathrm{Al}_{2} \mathrm{O}_{3}$ & 19.42 & 17.10 & 20.57 & 17.28 & 18.62 & 13.59 & 16.93 & 10.89 & 11.02 & 15.35 & 14.88 & 11.74 & 28.60 \\
\hline $\mathrm{FeO}$ & 3.68 & 7.80 & 4.91 & 3.28 & 3.21 & 3.84 & 10.29 & 12.83 & 11.03 & 8.93 & 8.85 & 10.05 & 2.90 \\
\hline $\mathrm{MnO}$ & 0.07 & 0.27 & 0.08 & - & 0.09 & 0.11 & 0.00 & 0.12 & 0.12 & 0.00 & 0.15 & 0.00 & 0.04 \\
\hline $\mathrm{MgO}$ & 9.25 & 7.08 & 3.55 & 9.09 & 6.95 & 7.77 & 7.13 & 12.87 & 11.07 & 6.24 & 7.15 & 12.44 & 3.30 \\
\hline $\mathrm{CaO}$ & 15.56 & 13.00 & 20.26 & 20.01 & 20.70 & 25.08 & 10.05 & 13.09 & 16.89 & 14.77 & 14.24 & 19.41 & 16.00 \\
\hline $\mathrm{Na}_{2} \mathrm{O}$ & 1.70 & 2.42 & 2.46 & 1.51 & 1.46 & 1.74 & 3.21 & 1.63 & 1.40 & 2.91 & 3.14 & 0.87 & 1.60 \\
\hline $\mathrm{K}_{2} \mathrm{O}$ & 0.01 & 0.02 & 0.09 & 0.01 & 0.01 & 0.01 & 0.00 & 0.11 & 0.10 & 0.02 & 0.40 & 0.00 & 0.12 \\
\hline $\mathrm{CO}_{2}$ & 0.00 & 0.00 & 8.10 & 4.84 & 10.05 & 13.51 & 0.00 & 5.00 & 4.42 & 4.43 & 4.40 & 15.38 & 0.00 \\
\hline $\mathrm{H}_{2} \mathrm{O}$ & 0.00 & 0.00 & 0.96 & 0.38 & 3.74 & 0.48 & 0.00 & 0.00 & 0.00 & 0.06 & 0.50 & 0.00 & 0.00 \\
\hline Total & 99.01 & 96.63 & 99.34 & 100.24 & 100.00 & 99.78 & 99.99 & 99.91 & 99.92 & 99.94 & 100.37 & 100.00 & 98.27 \\
\hline $\mathrm{Mg} /(\mathrm{Mg}+\mathrm{Fe})$ & 0.818 & 0.618 & 0.563 & 0.832 & 0.794 & 0.783 & 0.553 & 0.641 & 0.641 & 0.555 & 0.59 & 0.688 & 0.670 \\
\hline $\mathrm{Ca} /(\mathrm{Ca}+\mathrm{Mg}+\mathrm{Fe})$ & 0.497 & 0.449 & 0.698 & 0.568 & 0.630 & 0.644 & 0.359 & 0.319 & 0.413 & 0.485 & 0.466 & 0.436 & 0.700 \\
\hline or & 0.06 & 0.12 & 0.00 & 0.00 & 0.00 & 0.00 & 0.00 & 0.68 & 0.00 & 0.12 & 2.44 & 0.00 & 0.71 \\
\hline$a b$ & 15.11 & 22.38 & 0.00 & 0.00 & 0.00 & 0.00 & 28.67 & 5.04 & 0.00 & 17.20 & 10.61 & 0.00 & 13.98 \\
\hline an & 44.87 & 36.81 & 49.00 & 41.51 & 50.14 & 33.23 & 31.62 & 23.14 & 24.61 & 29.99 & 26.21 & 32.53 & 71.04 \\
\hline lc & 0.00 & 0.00 & 0.46 & 0.05 & 0.05 & 0.05 & 0.00 & 0.00 & 0.50 & 0.00 & 0.00 & 0.00 & 0.00 \\
\hline ne & 0.00 & 0.00 & 14.49 & 8.37 & 8.92 & 10.65 & 0.00 & 6.18 & 7.90 & 6.02 & 11.10 & 5.42 & 0.30 \\
\hline di & 25.23 & 23.70 & 17.12 & 37.42 & 4.96 & 4.05 & 14.38 & 35.95 & 46.74 & 37.12 & 39.40 & 0.00 & 7.05 \\
\hline hy & 6.86 & 8.31 & 0.00 & 0.00 & 0.00 & 0.00 & 19.72 & 0.00 & 0.00 & 0.00 & 0.00 & 0.00 & 0.00 \\
\hline ol & 6.18 & 4.96 & 4.81 & 6.77 & 16.02 & 19.19 & 4.05 & 21.84 & 11.62 & 7.91 & 5.09 & 28.63 & 5.08 \\
\hline $\mathrm{mt}$ & 1.61 & 2.52 & 1.94 & 1.67 & 1.83 & 1.83 & 1.56 & 4.01 & 4.03 & 1.63 & 3.20 & 1.81 & 1.67 \\
\hline il & 0.08 & 1.21 & 0.30 & 0.07 & 0.06 & 0.06 & 0.00 & 3.15 & 3.18 & 0.00 & 1.93 & 0.00 & 0.13 \\
\hline ap & 0.00 & 0.00 & 0.46 & 0.00 & 0.00 & 0.00 & 0.00 & 0.00 & 0.00 & 0.00 & 0.00 & 0.00 & 0.04 \\
\hline wus & 0.00 & 0.00 & 0.00 & 0.00 & 0.00 & 0.00 & 0.00 & 0.00 & 0.00 & 0.00 & 0.00 & 7.96 & 0.00 \\
\hline
\end{tabular}

59-3 olivine gabbro from Southwest Indian Ridge (Meyer et al. 1989), A1-2 altered gabbro from Southwest Indian Ridge (Bach et al. 2001), 59-3-ccb bulk composition obtained from composition 59-3 by adding 11 wt.\% calcite and 1.24 wt.\% brucite, 59-3-ccb-CA bulk composition used in sandwich experiments adding Al(OH) ${ }_{3}$ and silica to composition 59-3-ccb, 59-3-ccb-CB this composition differs from 59-3-ccb-CA because of it volatile composition and therefore Al, and Si addition, OTB starting material used in Poli et al (2009), SLEC 1 and SLEC3 carbonated eclogite compositions (Dasgupta et al. 2005), OTBC hydrated and carbonated material used in Hammouda (2003), GA1cc composition used in Kiseeva et al (2012), EC1 composition used in Yaxley and Brey (2004), Witt composition as used by Wittenberg (1997)

toward zoisite/anorthite compositions in a ACF projection (Fig. 3). Upper bound of chemical variability is represented by the plagioclase cumulate investigated by Wittenberg et al. (2003) and the lower bound by composition SLEC1 used by Dasgupta et al. (2004). The dispersion of the bulk compositions experimentally explored well reproduces varying proportions of pyroxene-olivine versus plagioclase.

In order to promote the synthesis at subsolidus conditions, a gel of chemical composition corresponding to samples 59-3 and 80-3 (Table 1) has been prepared using tetraethylorthosilicate (TEOS) as silica source, pure $\mathrm{Na}-, \mathrm{Ca}-, \mathrm{Mg}-$, and $\mathrm{Al}-$ nitric solutions, and ferric benzoate for $\mathrm{Fe}_{2} \mathrm{O}_{3}$. Gels have the major advantage of a large active surface, and perfect homogeneity, related to the co-precipitation of a hydrogel from clear solutions.
Gels were fired in a gas mixing furnace at $f \mathrm{O}_{2}$ conditions approaching FMQ buffer at $1 \mathrm{~atm}$, then seeded with 3 wt.\% of a mixture of garnets and clinopyroxene, that are expected to be major phases stable in the pressure range investigated. Individual seed composition (synthetic pyrope, almandine, grossular, diopside) largely differs from the stable composition expected at P-T conditions investigated to favour unquestionable identification of relicts, but the composition of seeds mixture closely reproduces the bulk composition chosen to avoid fractionation. Seeding is required to prevent from the nucleation of metastable phases, which is a potential problem notably in volatile-rich compositions. Seeded gels are of superior homogeneity and reactivity compared to fully crystalline mixtures, grinded glasses, or oxide mixtures at subsolidus or near-solidus pressure-temperature 


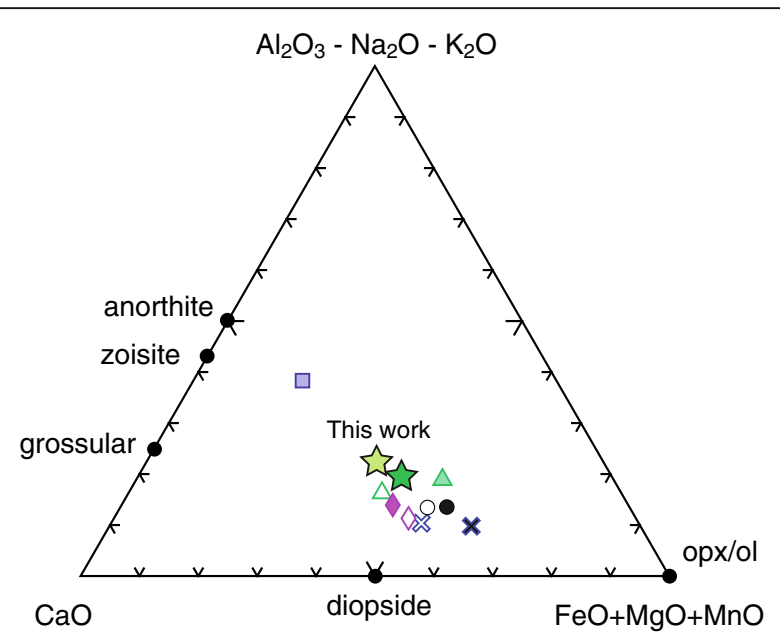

Fig. 3 ACF diagram of bulk compositions used in this study (stars) compared with compositions adopted in previous studies. Cross, Dasgupta et al. (2005); filled cross, Dasgupta et al. (2004); circle, Pawley and Holloway (1993); solid circle, Forneris and Holloway (2003); diamond, Yaxley and Brey (2004); solid diamond, Kiseeva et al. (2012); triangle, Hammouda (2003); solid triangle, Poli et al. 2009; solid square, Wittenberg et al. (2003)

conditions. Furthermore, as a conventional "bracketing" of mineral compositions (e.g., re-running experimental charges at different pressure and temperature) is hampered by the low reactivity of fully crystalline run products, growth rims on seeds of variable compositions (e.g., almandine vs. pyrope vs. grossular) are profitably used to evaluate the approach to equilibrium.

$\mathrm{H}_{2} \mathrm{O}$ and $\mathrm{CO}_{2}$ were added following three distinct experimental strategies:

(i) $\mathrm{H}_{2} \mathrm{O}$ and $\mathrm{CO}_{2}$ were added by oxalic acid dihydrate, which provides a source of volatiles decoupled from chemical variations of non-volatile components;

(ii)volatile addition has been related to the precipitation of secondary minerals chemical, in order to reproduce the chemical and mineralogical composition of altered gabbros, for example, as recorded in ODP Hole 735B (sample A1-2, Bach et al. 2001). Addition of 11 wt.\% calcite (cc) and 1.24 wt.\% brucite (br) therefore resulted to starting material 59-3-ccb (Table 1). Differences in the composition of starting material 59-3ccb as compared to 59-3 are expected to produce a higher amount of carbonate in the run products without altering phase relationships of silicates, in the range of pressure and temperature investigated here.

(iii) because high-pressure experiments in relatively An-rich bulk compositions are expected to produce kyanite, after reaction (6), a precise amounts of $\mathrm{H}_{2} \mathrm{O}$ in the run charge can be obtained by adding a bottom layer of $\mathrm{Al}(\mathrm{OH})_{3}$ and $\mathrm{SiO}_{2}$, which produce kyanite +
$\mathrm{H}_{2} \mathrm{O}$ under run conditions. Then, $\mathrm{CO}_{2}$ can be added as carbonates $\left(\mathrm{Na}_{2} \mathrm{CO}_{3}, \mathrm{CaCO}_{3}\right.$, natural dolomite $)$ as required to model variable $\mathrm{CO}_{2} / \mathrm{H}_{2} \mathrm{O}$ ratio and carbonate proportions (see below).

\section{Experimental setup}

A double-capsule technique was adopted in experiments with bulk composition 59-3 and 80-3. Hydrogen fugacity was buffered by hematite-magnetite ( $\mathrm{HM})-\mathrm{H}_{2} \mathrm{O}$ mixture, using inner $\mathrm{Ag}_{50} \mathrm{Pd}_{50}$ capsules and outer $\mathrm{Au}$ capsules. Welded inner capsules ( $2 \mathrm{~mm}$ long) contain the starting materials plus $10 \mathrm{wt}$.\% oxalic acid dihydrate (OAD). It is worth introducing here that HM buffer in the outer capsule fix the chemical potential of hydrogen in a pure $\mathrm{H}_{2} \mathrm{O}$ vapor, but the inner capsule contains a mixed vapor; as a consequence the oxygen fugacity in the inner capsule is intrinsically lower than in the outer capsule (see details in Poli et al., 2009). The actual value of the oxygen fugacity in the inner capsule is then fixed either by redox equilibria, or by a fixed $\mathrm{C} / \mathrm{O}$ ratio, or by the occurrence of graphite/diamond, however not observed here.

A second set of experiments was designed to investigate bulk composition 59-3 ccb at vapor-poor or vaporabsent conditions assuming that carbonate, epidote and, eventually, liquid fractionate most volatile components in this Ca-rich starting material. A single Au capsule was used for these runs.

A "sandwich" technique was used for a third set of experiments; a carbonate layer was inserted in 1:5 proportion between two layers of the same gel as used in the previous experimental setup, hereafter called "forward" setup (Fig. 4). The composition of the carbonate layer is based on the composition of carbonate quench products in the experiment at $900{ }^{\circ} \mathrm{C}, 4.2 \mathrm{GPa}$. It is therefore expected that phase proportions vary, to facilitate analytical characterization, but phase compositions remain unaltered (see discussion below).

High-pressure experiments were performed at pressures ranging from 3.7 to $4.6 \mathrm{GPa}$ and temperatures from 750 to $1000{ }^{\circ} \mathrm{C}$ at the Dipartimento di Scienze della Terra in Milano, Italy. Pressures lower than 4.0 GPa were investigated in an end-loaded piston cylinder, using $\mathrm{MgO}-$ salt assemblies. Temperature was measured by K-type thermocouple and was considered accurate to $\pm 5{ }^{\circ} \mathrm{C}$. A Walker-type multianvil apparatus was used for higher pressures using tungsten carbide cubes of $32 \mathrm{~mm}$ edge length and $17 \mathrm{~mm}$ truncation edge length (TEL), pressure cells made of prefabricated $\mathrm{MgO}$ octahedra (containing 5 wt.\% of $\mathrm{Cr}_{2} \mathrm{O}_{3}$ ) with a $25 \mathrm{~mm}$ edge length $(25 \mathrm{M})$. Pressure uncertainties, which largely depend on the accuracy of the calibrant reaction, were assumed to be $\pm 3 \%$. For further details, see Fumagalli and Poli (2005). Temperature was measured by S-type thermocouples and was considered accurate to $\pm 20{ }^{\circ} \mathrm{C}$ 


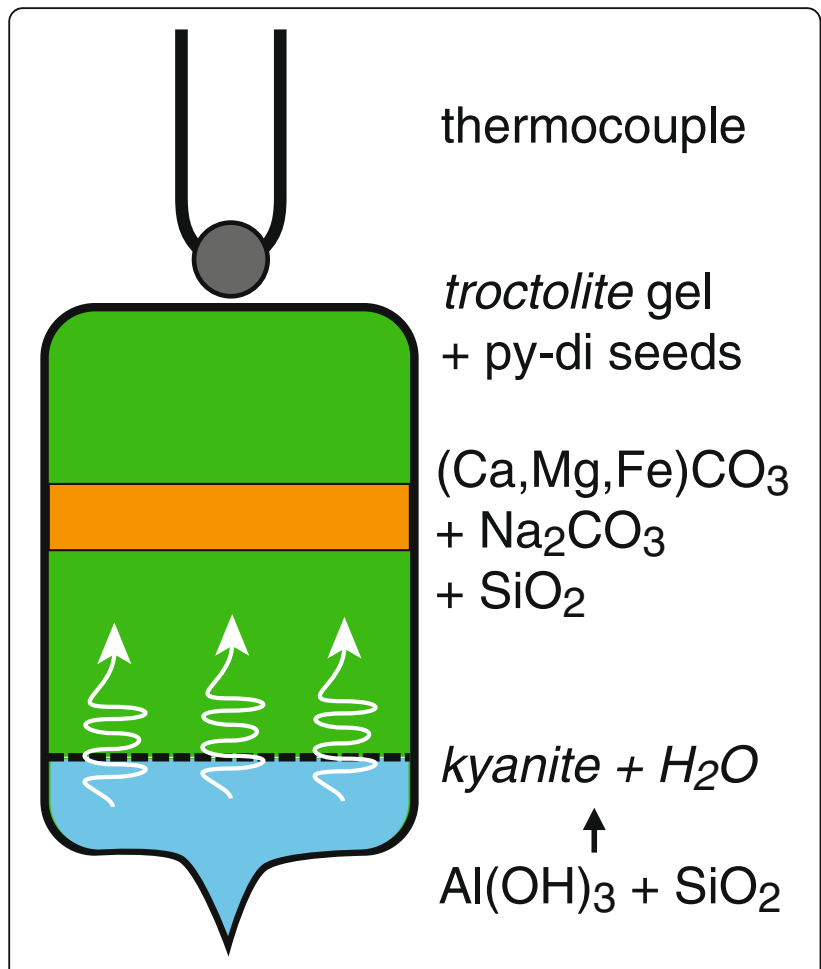

Fig. 4 Capsule geometry in "sandwich" experiments

without taking into account any effect of pressure on the e.m.f. of the thermocouple.

Run products were characterized by WDS electron microprobe analysis using a JEOL8200 Superprobe.

\section{Results}

\section{Phase assemblages and their textural features}

Garnet, clinopyroxene, and quartz/coesite were observed in all runs performed in this study (Fig. 5, Table 2). Texturally equilibrated garnet is present in most experiments, but among the minerals encountered in this study, garnet exhibits the most sluggish crystallization, with growth rims on seeds, mostly between 5 and $10 \mu \mathrm{m}$ thick, depending on temperature. Clinopyroxene nucleates from the starting material and constitutes mostly a matrix of small euhedral crystals. Kyanite was recognized in all run products other than those where lawsonite occurs. Hydrous phases are absent in all runs on starting material 80-3, with normative $A n=36.8$, the stability field of epidote therefore expected to be restricted to approximately 3.5 GPa in this bulk composition.

Lawsonite was recovered at $3.7 \mathrm{GPa}, 750{ }^{\circ} \mathrm{C}$, and 4.6 GPa, $700{ }^{\circ} \mathrm{C}$ in bulk composition $59-3$ and $59-3 \mathrm{ccb}$, as relatively large prismatic crystals, $20-40 \mu \mathrm{m}$ long (Fig. 6a). Epidote was found at $3.8 \mathrm{GPa}$, from 775 to $900{ }^{\circ} \mathrm{C}$, at the latter temperature as a minor phase coexisting with a quenched carbonate phase, interpreted here as precipitated from liquid (see below).

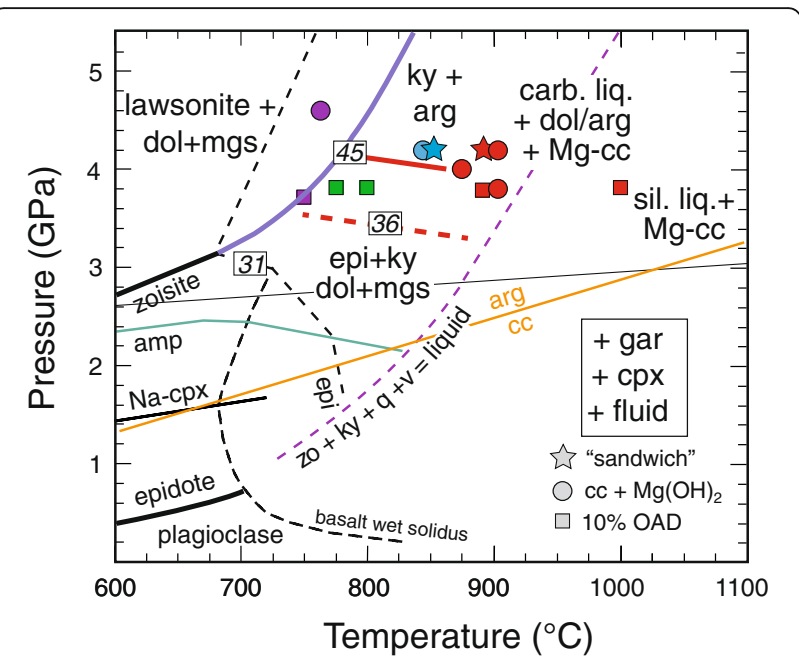

Fig. 5 Experimentally determined phase assemblages in model gabbros. Circles, experiments with oxalix acid dihydrate as volatile source; squares, experiments with brucite and carbonate; stars, sandwich experiments. Red symbols represent liquid-bearing experiments. Lines and numbers as in Fig. 1

All syntheses contain one or more carbonate phases. Magnesite and dolomite form when coexisting with $\mathrm{Ca}$ $\mathrm{Al}$-silicates, i.e., lawsonite or epidote (Fig. 6b). Nonetheless, magnesite was never observed in run products of experiments beyond the stability field of lawsonite or epidote, where, on the contrary a (Mg,Fe)-calcite and/or aragonite were found. The term Mg-calcite is used here for carbonate compositions where $\mathrm{Ca}>1.1$ atoms per formula unit. Subsolidus synthesis at $4.2 \mathrm{GPa}, 850{ }^{\circ} \mathrm{C}$, resulted in the assemblage garnet + clinopyroxene + aragonite + kyanite, showing that the transformation from calcite, to dolomite, then to magnesite bearing eclogite with increasing pressure (e.g., Kerrick and Connolly, 2001; Poli et al. 2009) depends largely on the bulk $\mathrm{Ca} /$ $(\mathrm{Ca}+\mathrm{Mg}+\mathrm{Fe})$ ratio. In this experiment, globules and droplets of both a silicate phase and a carbonate were recovered in the open porosity at the top of the capsule (see also Figure S3 in Poli 2015), therefore suggesting conspicuous dissolution of both silicates and carbonate in the high-pressure fluid.

All experiments performed at $900{ }^{\circ} \mathrm{C}$ show the occurrence of partial melting, with a variety of textural features as a function of volatile abundances. Experiments arranged in a double-capsule technique and oxalic acid dihydrate as $\mathrm{H}_{2} \mathrm{O}$ and $\mathrm{CO}_{2}$ source are expected to have a large amount of fluid present $(\approx 10 \mathrm{wt} . \%)$ and are characterized by the presence of large pools (in the order of a hundred micrometers large) of quench precipitates where silicate droplets are intermingled with carbonate aggregates and large skeletal crystals (Fig. 6c, d). The chemical composition of starting material $80-3$ is only slightly enriched in normative anorthite content 
Table 2 Summary of the starting material used, of experimental conditions, and of run products in order of abundance

\begin{tabular}{|c|c|c|c|c|c|c|c|c|c|c|c|}
\hline Run & Geometry & Bulk & $\mathrm{P}(\mathrm{GPa})$ & $\mathrm{T}\left({ }^{\circ} \mathrm{C}\right)$ & Duration (h) & $\mathrm{H}_{2} \mathrm{O}$ (wt.\%) & $\mathrm{CO}_{2}$ (wt.\%) & $\mathrm{CO}_{2} / \mathrm{H}_{2} \mathrm{O}$ (wt.\%) & $\begin{array}{l}\text { Carbonate st. } \\
\text { mat. (wt.\%) }\end{array}$ & Volatile source & Run products \\
\hline SPT1 & Double capsule & $59-3$ & 3.7 & 750 & 159 & 2.85 & 6.98 & 2.4 & - & OAD & $c p x+g a r+l a w+m g s+d o l+c s \pm$ epi \\
\hline SPT1-8 & Double capsule & $80-3$ & 3.7 & 750 & 159 & 2.85 & 6.98 & 2.4 & - & OAD & $c p x+g a r+m g s+d o l+k y+c s$ \\
\hline SPT2 & Double capsule & $59-3$ & 3.8 & 775 & 146 & 2.85 & 6.98 & 2.4 & - & OAD & $c p x+g a r+e p i+d o l+m g s+k y+c s$ \\
\hline SPT2-8 & Double capsule & $80-3$ & 3.8 & 775 & 146 & 2.85 & 6.98 & 2.4 & - & OAD & $c p x+g a r+m g s+d o l+k y+c s$ \\
\hline EFSP2 & Double capsule & $59-3$ & 3.8 & 800 & 110 & 2.85 & 6.98 & 2.4 & - & OAD & $c p x+g a r+e p i+d o l+m g s+k y+c s$ \\
\hline EFSP1 & Double capsule & $80-3$ & 3.8 & 800 & 110 & 2.85 & 6.98 & 2.4 & - & OAD & $\mathrm{cpx}+\mathrm{gar}+\mathrm{Mg}-\mathrm{cc}+\mathrm{ky}+\mathrm{cs}$ \\
\hline EFSP3 & Double capsule & $59-3$ & 3.8 & 900 & 92 & 2.85 & 6.98 & 2.4 & - & OAD & $\begin{array}{l}\mathrm{cpx}+\mathrm{gar}+\mathrm{Mg}-\mathrm{cc}+\text { glass + quench-cc } \\
+\mathrm{ky}+\mathrm{cs}\end{array}$ \\
\hline EFSP4 & Double capsule & $80-3$ & 3.8 & 900 & 92 & 2.85 & 6.98 & 2.4 & - & OAD & $\begin{array}{l}\mathrm{cpx}+\mathrm{gar}+\mathrm{Mg}-\mathrm{cc}+\mathrm{ky}+\mathrm{cs}+\text { quench-cc } \\
+ \text { quench-sil }\end{array}$ \\
\hline SPT3 & Double capsule & $59-3$ & 3.8 & 1000 & 121 & 2.85 & 6.98 & 2.4 & - & OAD & $\mathrm{cpx}+\mathrm{gar}+$ glass $+\mathrm{Mg}-\mathrm{cc}+\mathrm{ky}+\mathrm{cs}$ \\
\hline SPT3-8 & Double capsule & $80-3$ & 3.8 & 1000 & 121 & 2.85 & 6.98 & 2.4 & - & OAD & $\mathrm{cpx}+\mathrm{gar}+\mathrm{Mg}-\mathrm{cc}+\mathrm{ky}+\mathrm{glass}+\mathrm{cs}$ \\
\hline SPT7 & Single capsule & $59-3-c c b$ & 3.8 & 900 & 175 & 0.38 & 4.84 & 12.7 & 11 & $\mathrm{cc}+\mathrm{br}$ & $\begin{array}{l}\mathrm{cpx}+\mathrm{gar}+\mathrm{Mg}-\mathrm{cc}+\mathrm{epi}+\mathrm{cs} \\
+ \text { quench-cc } \pm \mathrm{ky}\end{array}$ \\
\hline FB6 & Single capsule & $59-3-c c b$ & 4.0 & 870 & 144 & 0.38 & 4.84 & 12.7 & 11 & $c c+b r$ & $c p x+g a r+a r g+$ quench-cc $+k y+c s$ \\
\hline SPT5 & Single capsule & $59-3-c c b$ & 4.2 & 900 & 105 & 0.38 & 4.84 & 12.7 & 11 & $\mathrm{cc}+\mathrm{br}$ & $\begin{array}{l}\text { cpx }+ \text { gar }+ \text { arg }+ \text { dol }+ \text { quench-cc } \\
+ \text { glass }+ \text { ky }+c s\end{array}$ \\
\hline SPT6 & Single capsule & $59-3-c c b$ & 4.2 & 850 & 316 & 0.38 & 4.84 & 12.7 & 11 & $c c+b r$ & $c p x+g a r+a r g+k y+c s$ \\
\hline SPT4 & Single capsule & $59-3-c c b$ & 4.6 & 700 & 264 & 0.38 & 4.84 & 12.7 & 11 & $c c+b r$ & $c p x+g a r+l a w+d o l+c s$ \\
\hline SPT9 & Sandwich & 59-3-ccb-CA & 4.2 & 850 & 86 & 3.7 & 10 & 2.7 & 26.7 & $\mathrm{Al}(\mathrm{OH})_{3}+\mathrm{cc}+\mathrm{br}$ & $\begin{array}{l}\mathrm{cpx}+\mathrm{gar}+\mathrm{arg}+\mathrm{dol}+\mathrm{ky}+\mathrm{cs} \\
+ \text { quench drops }\end{array}$ \\
\hline SPT8 & Sandwich & 59-3-ccb-CA & 4.2 & 900 & 234 & 3.7 & 10 & 2.7 & 26.7 & $\mathrm{Al}(\mathrm{OH})_{3}+\mathrm{cc}+\mathrm{br}$ & $\begin{array}{l}\mathrm{cpx}+\text { gar }+ \text { quench-cc }+ \text { glass }+ \text { arg } \\
+\mathrm{Mg}-\mathrm{cc}+\mathrm{ky}+\mathrm{cs}\end{array}$ \\
\hline SPT10 & Sandwich & 59-3-ccb-CB & 4.2 & 900 & 185 & 0.4 & 13.5 & 33.8 & 31 & $\mathrm{Al}(\mathrm{OH})_{3}+\mathrm{cc}+\mathrm{br}$ & $\begin{array}{l}\mathrm{cpx}+\text { gar }+ \text { quench-cc + glass }+ \text { arg } \\
+\mathrm{Mg}-\mathrm{cc}+\mathrm{ky}+\mathrm{cs}\end{array}$ \\
\hline
\end{tabular}

Run indicates experiments also discussed in Poli (2015). Geometry: double capsule indicates synthesis experiments performed at vapor saturation, buffered at HM in the outer capsule; single capsule stands for experiments in single Au capsule, with an amount of volatiles adjusted to stabilize hydrous phases and carbonates only (see the "Methods" section); sandwich is for experiments in a single Au capsule, where a layer of carbonates is placed in between two layers of gels. $\mathrm{H}_{2} \mathrm{O}, \mathrm{CO}_{2}$, and $\mathrm{CO}_{2} / \mathrm{H}_{2} \mathrm{O}$ are the total weight proportions and ratios of volatiles in the bulk composition. Carbonate st. mat. is the total amount of carbonate in the starting material, in weight proportions. Bulk: bulk composition of starting materials; 59-3 and 59-3-ccb: see Table 1; 59-3-ccb-CA: composition 59-3 with addition of a layer of Ca, Mg, Fe, and Na carbonates, simulating the liquid produced at $4.2 \mathrm{GPa}, 900{ }^{\circ} \mathrm{C}$ (see Tables $3,4,5,6,7$, and 8), and a layer of $\mathrm{Al}(\mathrm{OH})_{3}+\mathrm{SiO}_{2}$, producing kyanite $+\mathrm{H}_{2} \mathrm{O}$ at run conditions. Volatile sources - OAD oxalic acid dihydrate, $c \mathrm{c}$ calcite, br brucite. Run products - arg aragonite, cs coesite, cpx omphacite, dol dolomite, epi epidote, gar garnet, glass silicate glass, ky kyanite, law lawsonite, Mg-cc (Mg,Fe)-calcite, mgs magnesite, quench-cc Ca-rich carbonate in dendritic, fea-

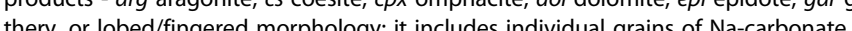



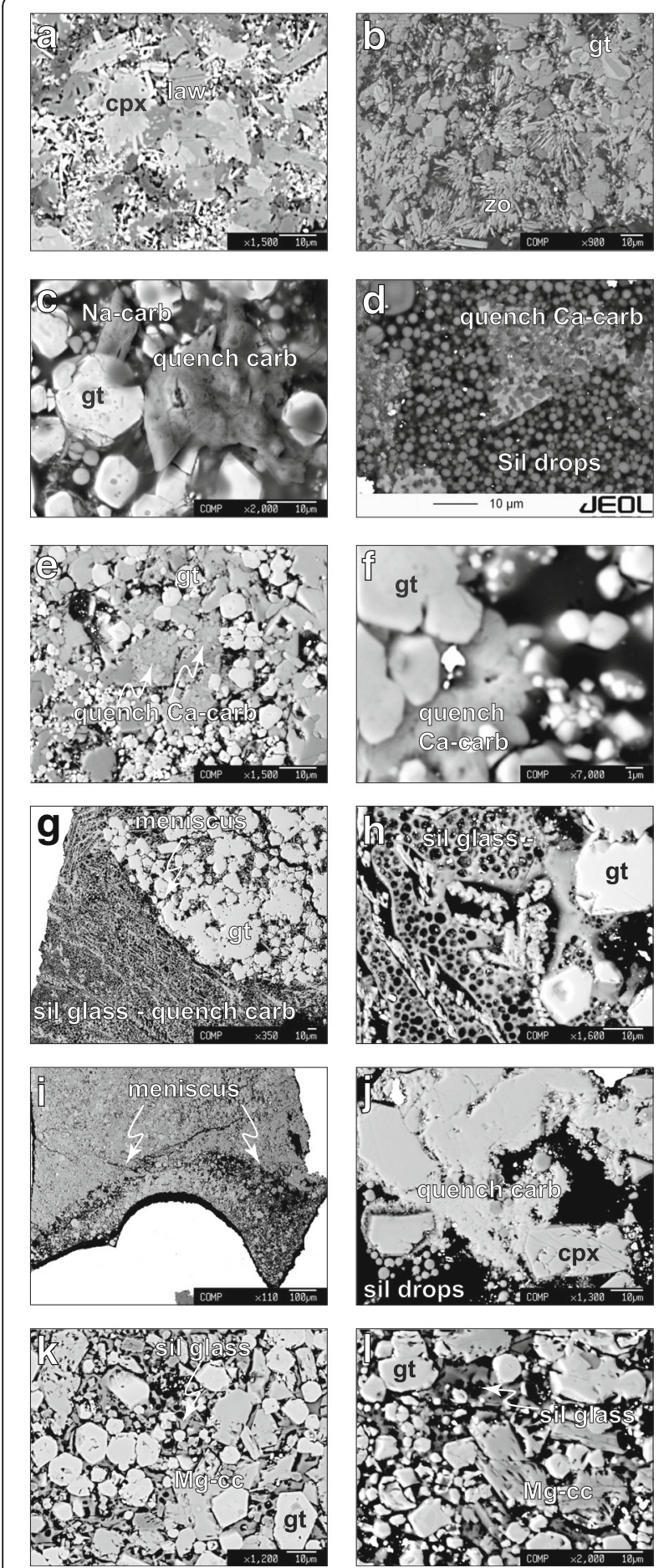

Fig. 6 Back-scattered electron images of representative run products. a $3.7 \mathrm{GPa}$ at $750^{\circ} \mathrm{C}$, run SPT1; b $3.8 \mathrm{GPa}$ at $800^{\circ} \mathrm{C}$, run EFSP1; c $3.8 \mathrm{GPa}$ at $900{ }^{\circ} \mathrm{C}$, run EFSP3; d $3.8 \mathrm{GPa}$ at $900^{\circ} \mathrm{C}$, run EFSP4; e $4.0 \mathrm{GPa}$ at $870{ }^{\circ} \mathrm{C}$, run FB6; $f$ 4.2 GPa at $900{ }^{\circ} \mathrm{C}$, run SPT5; $\mathbf{g}, \mathbf{h} 4.2 \mathrm{GPa}$ at $900^{\circ} \mathrm{C}$, sandwich experiment $\mathrm{SPT} 8, \mathrm{CO}_{2} / \mathrm{H}_{2} \mathrm{O}=2.7 ; \mathbf{i}$, j $4.2 \mathrm{GPa}$ at $900{ }^{\circ} \mathrm{C}$, sandwich experiment SPT10, $\mathrm{CO}_{2} / \mathrm{H}_{2} \mathrm{O}=33.8 ; \mathbf{k} 3.8 \mathrm{GPa}$ at $1000{ }^{\circ} \mathrm{C}$, run SPT3, bulk 593; I $3.8 \mathrm{GPa}$ at $1000{ }^{\circ} \mathrm{C}$, run SPT3-8, bulk 803
( $A n=36.8$ in $80-3$, Table 1, compared to $A n=31.6$ in OTB, Poli et al. 2009) and epidote is absent a $3.8 \mathrm{GPa}$; nonetheless, its vapor-saturated solidus shows the presence of a carbonatitic component in the liquids formed (Fig. 6d). Therefore, although this contribution will mainly focus on bulk compositions accounting for the stability of epidote up to $4 \mathrm{GPa}$, and on its consequences on the features of the solidus reactions at such pressure, it is worth pointing out that vapor saturation, e.g., achieved by fluidflushing, on even mildly $A n$-enriched lithologies may result in extended carbonate dissolution in liquids formed.

The composition of the carbonate phase precipitated is in most cases in the ternary $\mathrm{Ca}-\mathrm{Mg}$-Fe field, but $\mathrm{Na}$ carbonate is also observed (Fig. 6c). Whether quench textures observed in these volatile-rich experiments are the result of the precipitation of a single volatile-rich carbonate-silicate liquid, of a liquid coexisting with a solute-rich fluid, of two liquids (one silicate, the second carbonatitic) or, as an extreme case, of three "liquids," one silicate, the second carbonatitic, and the third, the solute-rich fluid, it is impossible to discern.

A set of experiments (Table 2) was conducted to reduce the amount of volatiles in the run charge; nonetheless, they show the appearance of dendritic aggregates of a carbonate phase at $4.0 \mathrm{GPa}, 870{ }^{\circ} \mathrm{C}$ (Fig. 6e), and, most notably, small pools with lobe and cusp structures (Fig. 6f) at $3.8-4.2 \mathrm{GPa}, 900{ }^{\circ} \mathrm{C}$. Lobe and cusp structures are known to develop during viscous fingering moved by Saffman-Taylor instabilities in liquids of contrasting viscosities (e.g., Perugini and Poli, 2005), and their coexistence with whiskery crystals strongly suggests the occurrence of more than a single liquid on quenching of these experiments. Again, quench textures do not unequivocally indicate how many liquids occurred at run conditions and the determination of the composition of such liquids is hampered by the size of quench products. Sandwich experiments (Fig. 4) at variable $\mathrm{CO}_{2} / \mathrm{H}_{2} \mathrm{O}$ ratio (Table 2) were therefore introduced in order to highlight the relationships between precipitates and to preserve large areas of molten material to retrieve compositional features. Run products at $4.2 \mathrm{GPa}, 900{ }^{\circ} \mathrm{C}$, are characterized by a segregated fraction at the hot end of the capsule, close to the thermocouple, delimited by a meniscus (Fig. 6g, i). Precipitated intergrowths from the run charge with 3.7 wt.\% $\mathrm{H}_{2} \mathrm{O}$ added show a peculiar texture characterized by a silicate glass foamed by micrometer-sized vesicles, where long dendrites of carbonate (Fig. 6h) are often arranged to form a rhombohedral grid. It is worth noting that rims of silicate glass are not fragmented and vesicularity is less pronounced. Minor silica globules are found at some interstices. $\mathrm{Na}$ carbonate dendrites are recovered (see also Figure S4 in Poli 2015). Euhedral (Mg,Fe)-calcite coexist with garnet and clinopyroxene in the residue. 
The absence of a continuous porosity and/or large vesicles (Fig. 6g) supports the absence of a free fluid at run conditions. Such textural features can be therefore interpreted as a precipitation sequence upon quenching of a single volatile-rich "liquid" phase. Because ( $\mathrm{Ca}, \mathrm{Mg}, \mathrm{Fe})$ carbonate liquids cannot be vitrified, carbonate dendrites precipitate first; a free fluid phase, solute-rich, separates from the silicate "residual liquid" afterwards; progression of quenching is finally responsible for the precipitation of the solute from the fluid in the form of silicate droplets and Na-carbonate. The carbonate layer is entirely liquefied in this experiment, so the amount of volatiles dissolved in the liquid formed can be estimated at $\approx 20$ wt. $\% \mathrm{H}_{2} \mathrm{O}$ and $\approx 25$ wt. $\% \mathrm{CO}_{2}$.

On the contrary, run charge with 0.4 wt. $\% \mathrm{H}_{2} \mathrm{O}$ and 13.4 wt.\% $\mathrm{CO}_{2}$, produced a continuous porosity at the top of the capsule (Fig. 6i), and dendritic aggregates of carbonate are intermingled with silicate globules (Fig. 6j). The carbonate layer is partly preserved, and partial melting in the presence of a fluid is therefore likely in this case.

Experiments at $1000{ }^{\circ} \mathrm{C}$ were produced with $\mathrm{OAD}$ as a volatile source and generated large pools of silicate glass coexisting with large euhedral Mg-calcite crystals (Fig. 6k, l). Again, vesicularity suggests the exsolution of the fluid phase on quenching of the silicate liquid.

\section{Phase compositions and the representativeness of sandwich experiments}

Representative analyses of run products are reported in Tables 3, 4, 5, 6, 7, and 8. All experiments at run conditions include a "fluid" or a "liquid" of variable chemical composition. Quench microstructural features unequivocally indicate the presence of large amounts of nonvolatile solutes in "fluids" and of volatile components in "liquids." Heterogeneous spatial distribution of quench products hinders an analytical estimate of the amount of solutes in fluids and of volatile components in liquids. As a consequence, phase proportions by a mass balance approach are not given here.

Garnet and clinopyroxene display major variations in cation distribution with temperature (Fig. 7) and, therefore, phase assemblages. As expected, $\mathrm{Mg} /(\mathrm{Mg}+\mathrm{Fe})$ ratio (and $\mathrm{Mg}$ concentration) in garnet increases with temperature from 0.5 , at $700{ }^{\circ} \mathrm{C}$, to approximately 0.7 , at $800{ }^{\circ} \mathrm{C}$, in the subsolidus, up to 0.76 at $1000{ }^{\circ} \mathrm{C}$ in the presence of the silicate liquid. Similarly, Ca decreases from 1.5 a.p.f.u. down to 0.9 a.p.f.u. (not shown). The group of experiments at $870-900{ }^{\circ} \mathrm{C}$, where a carbonatitic liquid is observed, is shifted systematically to lower $\mathrm{Mg} /$ $(\mathrm{Mg}+\mathrm{Fe})$ and higher $\mathrm{Ca}$ compared to this trend. Unexpectedly, data retrieved at $850{ }^{\circ} \mathrm{C}$ cluster with this group, possibly suggesting that a liquid might have occurred, though overlooked. These experiments were performed on different bulk compositions related to varying proportions of carbonates and silicates, as discussed in the "Methods" section (Table 1). Similarly, clinopyroxene shows an increase of the $\mathrm{Mg}$ content with temperature from 700 to $800{ }^{\circ} \mathrm{C}$. Again, all experiments at $850-900{ }^{\circ} \mathrm{C}$ are clustered at $\mathrm{Mg} /(\mathrm{Mg}+\mathrm{Fe}) 0.8-0.9$ in the variety of experimental charge setup. Notably, the composition of both garnets and clinopyroxene produced at $4.2 \mathrm{GPa}, 900{ }^{\circ} \mathrm{C}$, in forward experiments and in the two different sandwich experiments, at variable $\mathrm{CO}_{2} / \mathrm{H}_{2} \mathrm{O}$ ratio, are identical within error bars.

Sandwich experiments have been proposed to investigate the composition of small degree partial melts. On principle, at equilibrium, the chemical potential of components in the liquid and in the coexisting solids is identical independently on their relative abundances; therefore, provided the phase assemblage obtained is identical, the chemical composition of liquids in "forward" and sandwich experiments should not differ, whereas liquid proportions vary, thus facilitating analytical characterization. However, on practical application, this method presents a potential pitfall (Hirschmann and Dasgupta 2007) given by the uncertainty in estimating the starting "equilibrium" composition; a deviation from equilibrium composition may lead to shifts in bulk compositions affecting final phase compositions, and ultimately phase assemblage. Iterations are then commonly required to obtain convergence to expected element concentrations at true equilibrium.

Sandwich experiment SPT8 was constructed placing a layer of a carbonate mixture $(15 \%$ in weight, on the total amount of starting material) based on the composition of the liquid as measured in lobes for the run charge SPT5 (Fig. 6f), between two layers of the model gabbro constituting the starting material of experiment SPT5. Silica and $\mathrm{Al}(\mathrm{OH})_{3}$ were added to provide $3.7 \mathrm{wt} . \% \mathrm{H}_{2} \mathrm{O}$ in the starting material and kyanite saturation. Similarly, experiment SPT10 was run with 22 wt.\% carbonate layer and $\mathrm{Al}(\mathrm{OH})_{3}$ to obtain 0.48 wt.\% $\mathrm{H}_{2} \mathrm{O}$ (Table 1).

Despite the differences in the bulk composition of the experimental charge, due to the different proportions in carbonates, silicates, and volatile sources, we obtained identical $\mathrm{Mg} /(\mathrm{Mg}+\mathrm{Fe})$ ratio in clinopyroxenes of the three experimental setups at $4.2 \mathrm{GPa}, 900{ }^{\circ} \mathrm{C}$, in "forward" and sandwich experiments. Although the composition of garnet in SPT10 is slightly shifted to lower $\mathrm{Mg} /(\mathrm{Mg}+\mathrm{Fe})$, again the compositions in the three syntheses are comparable.

Carbonate phases show high $\mathrm{Mg} /(\mathrm{Mg}+\mathrm{Fe})\left(\mathrm{X}_{\mathrm{Mg}}\right)$, $0.88-0.91$ in magnesite, 0.88 in dolomite, and $0.80-0.85$ in (Mg,Fe)-calcite at $850-900{ }^{\circ} \mathrm{C}$, but up to 0.9 at $1000^{\circ}$ C. Carbonate dendrites from quenched liquids at $900{ }^{\circ} \mathrm{C}$ have much lower $\mathrm{X}_{\mathrm{Mg}}, 0.55$ in "forward" experiment SPT5 where small pools are analyzed, and 0.72 in sandwich experiment SPT8 (Table 8). Although such 
Table 3 Chemical composition of clinopyroxene. Units are weight percent of oxides and atoms per formula unit. $X_{M g}=\mathrm{Mg} /(\mathrm{Mg}+\mathrm{Fe})$

\begin{tabular}{|c|c|c|c|c|c|c|c|}
\hline Run & SPT1 & EFSP2 & SPT2 & EFSP3 & SPT3 & SPT4 & SPT5 \\
\hline$P(\mathrm{GPa})$ & 3.7 & 3.8 & 3.8 & 3.8 & 3.8 & 4.6 & 4.2 \\
\hline$T\left({ }^{\circ} \mathrm{C}\right)$ & 750 & 800 & 775 & 900 & 1000 & 700 & 900 \\
\hline $\mathrm{SiO}_{2}$ & $55.80(1.67)$ & $54.11(1.15)$ & $56.52(0.14)$ & $54.22(0.22)$ & $55.20(1.17)$ & $54.67(0.32)$ & $54.97(0.42)$ \\
\hline $\mathrm{Al}_{2} \mathrm{O}_{3}$ & $12.83(2.70)$ & $6.54(1.02)$ & $8.44(1.01)$ & $13.14(1.54)$ & $12.00(1.15)$ & $11.34(0.42)$ & $16.25(0.59)$ \\
\hline $\mathrm{FeO}$ & $2.75(0.33)$ & $2.08(0.54)$ & $2.53(0.17)$ & $3.65(1.00)$ & $1.89(0.38)$ & $3.05(0.21)$ & $1.81(0.16)$ \\
\hline $\mathrm{MgO}$ & $8.58(0.95)$ & $13.56(0.55)$ & $11.38(0.69)$ & $8.71(1.16)$ & $11.07(0.40)$ & $10.23(0.33)$ & $8.29(0.26)$ \\
\hline $\mathrm{CaO}$ & $14.73(1.08)$ & $21.14(0.61)$ & $18.00(0.86)$ & $13.39(1.24)$ & $17.21(0.55)$ & $18.04(0.45)$ & $13.92(0.30)$ \\
\hline $\mathrm{Na}_{2} \mathrm{O}$ & $5.71(0.80)$ & $1.99(0.11)$ & $4.03(0.37)$ & $5.80(0.77)$ & $3.79(0.30)$ & $3.66(0.28)$ & $5.50(0.22)$ \\
\hline Total & $100.39(1.07)$ & $99.43(1.45)$ & $100.89(0.15)$ & $98.90(0.86)$ & $101.17(1.36)$ & $100.99(0.21)$ & $100.74(0.47)$ \\
\hline $\mathrm{Si}$ & $1.961(0.051)$ & $1.952(0.024)$ & $1.991(0.004)$ & $1.948(0.014)$ & $1.928(0.016)$ & $1.928(0.008)$ & 1.909 (0.009) \\
\hline Al & $0.531(0.110)$ & $0.279(0.047)$ & $0.350(0.041)$ & $0.557(0.067)$ & $0.493(0.041)$ & $0.471(0.017)$ & $0.665(0.024)$ \\
\hline $\mathrm{Fe}^{2+}$ & $0.081(0.010)$ & $0.063(0.017)$ & $0.075(0.005)$ & $0.109(0.030)$ & $0.055(0.011)$ & $0.090(0.006)$ & $0.052(0.004)$ \\
\hline $\mathrm{Mg}$ & $0.450(0.053)$ & $0.729(0.021)$ & $0.598(0.038)$ & $0.466(0.061)$ & $0.577(0.029)$ & $0.538(0.018)$ & $0.429(0.014)$ \\
\hline $\mathrm{Ca}$ & $0.555(0.045)$ & $0.817(0.016)$ & $0.680(0.034)$ & $0.515(0.046)$ & $0.644(0.032)$ & $0.682(0.018)$ & $0.518(0.012)$ \\
\hline $\mathrm{Na}$ & $0.389(0.050)$ & $0.139(0.008)$ & $0.275(0.025)$ & $0.404(0.055)$ & $0.257(0.019)$ & $0.250(0.018)$ & $0.370(0.015)$ \\
\hline$X_{M g}$ & $0.848(0.012)$ & $0.921(0.019)$ & $0.888(0.011)$ & $0.812(0.022)$ & $0.913(0.015)$ & $0.857(0.010)$ & $0.891(0.010)$ \\
\hline Run & SPT6 & FB6 & SPT7 & SPT8 & SPT9 & SPT10 & \\
\hline$P(\mathrm{GPa})$ & 4.2 & 4.0 & 3.8 & 4.2 & 4.2 & 4.2 & \\
\hline$T\left({ }^{\circ} \mathrm{C}\right)$ & 850 & 870 & 900 & 900 & 850 & 900 & \\
\hline $\mathrm{SiO}_{2}$ & $55.17(0.52)$ & $54.52(0.99)$ & $54.88(0.80)$ & $56.35(0.44)$ & $56.58(0.61)$ & $56.49(0.44)$ & \\
\hline $\mathrm{Al}_{2} \mathrm{O}_{3}$ & $16.31(1.22)$ & $15.04(2.26)$ & $12.48(2.07)$ & $14.13(0.45)$ & $13.65(1.25)$ & $13.96(1.50)$ & \\
\hline $\mathrm{FeO}$ & $1.66(0.16)$ & $2.38(0.69)$ & $2.74(0.70)$ & $1.78(0.12)$ & $2.08(0.62)$ & $1.76(0.16)$ & \\
\hline $\mathrm{MgO}$ & $7.89(0.29)$ & $8.43(0.63)$ & $9.70(1.04)$ & $8.10(0.28)$ & $7.99(0.25)$ & $8.35(0.98)$ & \\
\hline $\mathrm{CaO}$ & $13.25(0.44)$ & $14.51(0.83)$ & $16.20(1.00)$ & $13.71(0.41)$ & $13.55(0.46)$ & $14.00(1.00)$ & \\
\hline $\mathrm{Na}_{2} \mathrm{O}$ & $5.71(0.39)$ & $4.94(0.42)$ & $4.61(0.52)$ & $6.20(0.38)$ & $6.27(0.31)$ & $6.05(0.45)$ & \\
\hline Total & $99.99(0.21)$ & $99.82(0.58)$ & $100.61(0.42)$ & $100.27(0.37)$ & $100.12(0.53)$ & $100.61(0.33)$ & \\
\hline $\mathrm{Si}$ & $1.924(0.020)$ & $1.918(0.037)$ & $1.932(0.026)$ & $1.966(0.009)$ & $1.979(0.020)$ & $1.965(0.007)$ & \\
\hline $\mathrm{Al}$ & $0.670(0.049)$ & $0.623(0.087)$ & $0.518(0.084)$ & $0.581(0.018)$ & $0.562(0.047)$ & $0.572(0.058)$ & \\
\hline $\mathrm{Fe}^{2+}$ & $0.048(0.005)$ & $0.070(0.020)$ & $0.081(0.021)$ & $0.052(0.004)$ & $0.061(0.019)$ & $0.051(0.005)$ & \\
\hline $\mathrm{Mg}$ & $0.410(0.015)$ & $0.442(0.035)$ & $0.509(0.056)$ & $0.421(0.016)$ & $0.417(0.014)$ & $0.433(0.054)$ & \\
\hline $\mathrm{Ca}$ & $0.495(0.017)$ & $0.547(0.035)$ & $0.611(0.040)$ & $0.512(0.016)$ & $0.508(0.020)$ & $0.522(0.041)$ & \\
\hline $\mathrm{Na}$ & $0.386(0.027)$ & $0.337(0.029)$ & $0.315(0.034)$ & $0.419(0.025)$ & $0.425(0.022)$ & $0.408(0.028)$ & \\
\hline$X_{M g}$ & $0.895(0.008)$ & $0.864(0.035)$ & $0.863(0.034)$ & $0.890(0.007)$ & $0.873(0.034)$ & $0.894(0.010)$ & \\
\hline
\end{tabular}

difference is apparently large, the two compositions are very enriched in calcium and within analytical uncertainty, at $\mathrm{Ca} /(\mathrm{Ca}+\mathrm{Mg}+\mathrm{Fe})=0.75-0.80$. Silicate glass intermingled with carbonate dendrites is variable in composition, though grossly tonalitic. $\mathrm{Ca}, \mathrm{Fe}$, and $\mathrm{Mg}$ contents usually do not sum up to more than 5 wt.\% total. Glass is most enriched in silica in the rims of large globules and in the smallest droplets, suggesting that composition varies along cooling, and therefore along precipitation sequence.

Iterations to further bracket liquid-solid element partitioning in forward and sandwich experiments was not performed yet, in this first study. Nonetheless, the consistency between garnet, clinopyroxene, and carbonate precipitated from the carbonatitic liquid support the representativeness of sandwich setup in reproducing phase relationships on the solidus of gabbroic eclogites.

Epidote compositions reveal a maximum $\mathrm{Fe}^{3+}$ content in the order of 0.10 a.p.f.u. based on 13 oxygens.

\section{Discussion}

Phase diagrams for the system $\mathrm{CaCO}_{3}-\mathrm{MgCO}_{3}-\mathrm{FeCO}_{3}$ Whenever $\mathrm{CO}_{2}$ is available, ternary ( $\left.\mathrm{Ca}, \mathrm{Mg}, \mathrm{Fe}\right)$-carbonates are common constituents of high-pressure 
Table 4 Chemical composition of garnet. Units are weight percent of oxides and atoms per formula unit. $\mathrm{X}_{\mathrm{Mg}}=\mathrm{Mg} /(\mathrm{Mg}+\mathrm{Fe})$

\begin{tabular}{|c|c|c|c|c|c|c|}
\hline Run & EFSP2 & SPT2 & EFSP3 & SPT3 & SPT4 & SPT5 \\
\hline$P(\mathrm{GPa})$ & 3.8 & 3.8 & 3.8 & 3.8 & 4.6 & 4.2 \\
\hline$T\left({ }^{\circ} \mathrm{C}\right)$ & 800 & 775 & 900 & 1000 & 700 & 900 \\
\hline $\mathrm{SiO}_{2}$ & $41.02(1.35)$ & $41.26(0.30)$ & $40.41(0.78)$ & $41.96(0.29)$ & $40.37(0.31)$ & $40.07(0.09)$ \\
\hline $\mathrm{Al}_{2} \mathrm{O}_{3}$ & $22.84(0.45)$ & $22.42(0.23)$ & $22.38(0.73)$ & $23.13(0.38)$ & $22.91(0.38)$ & $23.66(0.38)$ \\
\hline $\mathrm{Fe}_{2} \mathrm{O}_{3}$ & $0.00(0.00)$ & $0.00(0.00)$ & $0.80(0.96)$ & $0.33(0.46)$ & $0.32(0.31)$ & $0.41(0.22)$ \\
\hline $\mathrm{FeO}$ & $10.69(2.28)$ & $13.22(1.00)$ & $16.82(3.15)$ & $7.95(0.81)$ & $11.39(1.68)$ & $10.35(0.77)$ \\
\hline $\mathrm{MgO}$ & $12.46(1.31)$ & $9.82(0.79)$ & 9.67 (1.59) & $14.43(0.18)$ & $6.71(1.18)$ & $8.47(0.41)$ \\
\hline $\mathrm{CaO}$ & $12.17(0.60)$ & $14.04(0.32)$ & $10.48(0.84)$ & $12.57(0.44)$ & $19.28(1.51)$ & $17.27(0.24)$ \\
\hline $\mathrm{Na}_{2} \mathrm{O}$ & $0.02(0.02)$ & $0.01(0.01)$ & $0.09(0.08)$ & $0.06(0.04)$ & $0.02(0.02)$ & $0.05(0.06)$ \\
\hline Total & $99.21(3.02)$ & $100.78(0.57)$ & $100.65(2.53)$ & $100.43(0.80)$ & $101.00(0.60)$ & $100.27(0.33)$ \\
\hline $\mathrm{Si}$ & $3.023(0.046)$ & $3.042(0.009)$ & $3.014(0.050)$ & $3.018(0.018)$ & $2.992(0.011)$ & $2.962(0.013)$ \\
\hline $\mathrm{Al}$ & $1.984(0.020)$ & $1.949(0.012)$ & $1.967(0.037)$ & $1.961(0.021)$ & $2.001(0.025)$ & $2.061(0.024)$ \\
\hline $\mathrm{Fe}^{3+}$ & $0.000(0.000)$ & $0.000(0.000)$ & $0.044(0.054)$ & $0.018(0.024)$ & $0.018(0.017)$ & $0.023(0.012)$ \\
\hline $\mathrm{Fe}^{2+}$ & $0.658(0.138)$ & $0.816(0.064)$ & $1.051(0.211)$ & $0.478(0.047)$ & $0.706(0.105)$ & $0.640(0.050)$ \\
\hline $\mathrm{Mg}$ & 1.370 (0.159) & $1.079(0.083)$ & $1.074(0.175)$ & $1.548(0.021)$ & $0.740(0.125)$ & $0.934(0.041)$ \\
\hline $\mathrm{Ca}$ & $0.961(0.046)$ & $1.110(0.030)$ & $0.837(0.067)$ & $0.969(0.037)$ & $1.532(0.128)$ & $1.368(0.019)$ \\
\hline $\mathrm{Na}$ & $0.003(0.003)$ & $0.002(0.001)$ & $0.012(0.011)$ & $0.008(0.005)$ & $0.003(0.003)$ & $0.008(0.009)$ \\
\hline$X_{M g}$ & $0.675(0.071)$ & $0.569(0.038)$ & $0.496(0.079)$ & $0.758(0.019)$ & $0.504(0.062)$ & $0.585(0.027)$ \\
\hline Run & SPT6 & FB6 & SPT7 & SPT8 & SPT9 & SPT10 \\
\hline$P(\mathrm{GPa})$ & 4.2 & 4.0 & 3.8 & 4.2 & 4.2 & 4.2 \\
\hline$T\left({ }^{\circ} \mathrm{C}\right)$ & 850 & 870 & 900 & 900 & 850 & 900 \\
\hline $\mathrm{SiO}_{2}$ & $40.84(0.60)$ & $40.80(0.53)$ & $40.19(0.42)$ & $40.58(0.42)$ & $40.34(0.41)$ & $40.14(0.23)$ \\
\hline $\mathrm{Al}_{2} \mathrm{O}_{3}$ & $23.19(0.90)$ & $22.81(0.44)$ & $22.92(0.42)$ & $23.50(0.18)$ & $22.09(0.56)$ & $22.93(0.25)$ \\
\hline $\mathrm{Fe}_{2} \mathrm{O}_{3}$ & $0.27(0.58)$ & $0.00(0.00)$ & $0.42(0.54)$ & $0.38(0.40)$ & $0.03(0.10)$ & $0.26(0.22)$ \\
\hline $\mathrm{FeO}$ & $10.85(0.87)$ & $10.79(1.92)$ & $14.20(1.31)$ & $10.99(0.61)$ & $15.28(1.58)$ & $13.06(1.53)$ \\
\hline $\mathrm{MgO}$ & $8.11(0.40)$ & $8.68(2.18)$ & $7.63(0.72)$ & $8.42(0.34)$ & $5.54(0.71)$ & $7.50(1.12)$ \\
\hline $\mathrm{CaO}$ & $17.45(0.62)$ & $16.58(1.35)$ & $15.38(0.75)$ & $16.92(0.52)$ & $17.00(1.08)$ & $16.11(0.29)$ \\
\hline $\mathrm{Na}_{2} \mathrm{O}$ & $0.08(0.03)$ & $0.06(0.04)$ & $0.07(0.06)$ & $0.04(0.04)$ & $0.11(0.10)$ & $0.06(0.04)$ \\
\hline Total & $100.79(0.61)$ & $99.73(0.67)$ & $100.81(0.68)$ & $100.83(0.37)$ & $100.39(0.38)$ & $100.06(0.18)$ \\
\hline $\mathrm{Si}$ & $3.012(0.038)$ & $3.032(0.031)$ & $2.991(0.024)$ & $2.984(0.026)$ & $3.040(0.024)$ & $2.989(0.007)$ \\
\hline $\mathrm{Al}$ & $2.016(0.075)$ & $1.997(0.017)$ & $2.010(0.030)$ & $2.036(0.016)$ & $1.962(0.042)$ & $2.013(0.009)$ \\
\hline $\mathrm{Fe}^{3+}$ & $0.015(0.032)$ & $0.000(0.000)$ & $0.024(0.030)$ & $0.021(0.022)$ & $0.002(0.006)$ & $0.015(0.012)$ \\
\hline $\mathrm{Fe}^{2+}$ & $0.669(0.052)$ & $0.672(0.124)$ & $0.884(0.084)$ & $0.676(0.037)$ & $0.963(0.106)$ & $0.814(0.099)$ \\
\hline $\mathrm{Mg}$ & $0.891(0.044)$ & $0.960(0.224)$ & $0.845(0.076)$ & $0.922(0.038)$ & $0.621(0.075)$ & $0.832(0.117)$ \\
\hline $\mathrm{Ca}$ & $1.379(0.054)$ & $1.321(0.118)$ & $1.226(0.059)$ & $1.333(0.040)$ & $1.372(0.084)$ & $1.286(0.026)$ \\
\hline $\mathrm{Na}$ & $0.012(0.005)$ & $0.009(0.006)$ & $0.010(0.008)$ & $0.005(0.006)$ & $0.016(0.015)$ & $0.008(0.005)$ \\
\hline$X_{M g}$ & $0.566(0.027)$ & $0.583(0.096)$ & $0.483(0.042)$ & $0.570(0.021)$ & $0.392(0.049)$ & $0.501(0.067)$ \\
\hline
\end{tabular}

rocks, because of the relatively low $\mathrm{dP} / \mathrm{dT}$ slope of decarbonation reactions compared to dehydration reactions (Figure 4 in Poli and Schmidt 2002). Although experimental data reveal major complexities in carbonate phase diagrams, and natural occurrences highlight extreme compositional variability, these series have been mostly regarded as simple binary mangesite-siderite, and dolomite-ankerite solid solutions, the latter eventually coexisting with calcite/aragonite. Thermodynamic modeling of solids suffers from a very limited set of experimental data, especially in Fe-bearing systems; both the topology and the location of the liquidus surface in the ternary system is entirely unknown. The role of additional components (silica, alkali, $\mathrm{H}_{2} \mathrm{O}$ ) on the liquidus 
Table 5 Chemical composition of dolomite. Units are weight percent of oxides and atoms per formula unit

\begin{tabular}{|c|c|c|c|c|c|}
\hline Run & SPT1 & EFSP2 & SPT2 & SPT5 & ST9 \\
\hline$P(\mathrm{GPa})$ & 3.7 & 3.8 & 3.8 & 4.2 & 4.2 \\
\hline$T\left({ }^{\circ} \mathrm{C}\right)$ & 750 & 800 & 775 & 900 & 850 \\
\hline $\mathrm{FeO}$ & $4.44(0.67)$ & $4.04(0.76)$ & $4.51(0.14)$ & $3.66(0.39)$ & $0.43(0.15)$ \\
\hline $\mathrm{MgO}$ & $18.14(0.16)$ & $17.82(3.18)$ & $18.58(0.47)$ & $17.78(1.67)$ & $20.59(0.21)$ \\
\hline $\mathrm{CaO}$ & $28.45(1.39)$ & $30.37(1.85)$ & $29.57(0.76)$ & $31.25(0.69)$ & $30.93(0.84)$ \\
\hline $\mathrm{Na}_{2} \mathrm{O}$ & $0.12(0.11)$ & $0.10(0.05)$ & $0.17(0.09)$ & $0.04(0.02)$ & $0.01(0.01)$ \\
\hline $\mathrm{CO}_{2}$ & $48.24(0.01)$ & $47.52(3.30)$ & $47.37(0.94)$ & $46.36(1.71)$ & $47.08(0.68)$ \\
\hline Total & $99.39(0.37)$ & $99.84(6.55)$ & $100.19(2.29)$ & $99.10(3.20)$ & $99.05(1.55)$ \\
\hline $\mathrm{Fe}^{2+}$ & $0.113(0.017)$ & $0.104(0.017)$ & $0.117(0.004)$ & $0.097(0.013)$ & $0.011(0.004)$ \\
\hline $\mathrm{Mg}$ & $0.821(0.007)$ & $0.812(0.113)$ & $0.857(0.031)$ & $0.836(0.048)$ & $0.955(0.015)$ \\
\hline $\mathrm{Ca}$ & $0.926(0.044)$ & $1.005(0.044)$ & $0.980(0.011)$ & $1.059(0.036)$ & $1.031(0.017)$ \\
\hline $\mathrm{Na}$ & $0.007(0.007)$ & $0.006(0.004)$ & $0.010(0.005)$ & $0.002(0.001)$ & $0.000(0.000)$ \\
\hline C & $2.000(0.000)$ & $2.000(0.000)$ & $2.000(0.000)$ & $2.000(0.000)$ & $2.000(0.000)$ \\
\hline
\end{tabular}

surface introduces further complexities, far from being quantitatively addressable at present. Experimental results obtained here nonetheless introduce some major constraint on the topology of phase relationships at the solidus for hydrous carbonatitic melts.

Subsolidus relations in the system $\mathrm{CaCO}_{3}-\mathrm{MgCO}_{3}-$ $\mathrm{FeCO}_{3}$ have been computed using the Perple_X software (Connolly 1990, 2005) and an internally consistent thermodynamic data set (Holland and Powell 1998; and update). The recently developed solid solution model for ternary $\mathrm{Ca}-\mathrm{Fe}-\mathrm{Mg}$ carbonates (Franzolin et al. 2011) was used to determine the compositional variations, the transition of carbonate minerals, and the effect of Fe on the topology of phase diagrams. Figure 8 was calculated at a pressure of $3.5 \mathrm{GPa}$ because at such conditions, the

Table 6 Chemical composition of magnesite Units are weight percent of oxides and atoms per formula unit

\begin{tabular}{llll}
\hline Run & SPT1 & EFSP2 & SPT2 \\
\hline$P(\mathrm{GPa})$ & 3.7 & 3.8 & 3.8 \\
$T\left({ }^{\circ} \mathrm{C}\right)$ & 750 & 800 & 775 \\
$\mathrm{FeO}$ & $9.10(0.77)$ & $7.04(3.15)$ & $7.32(0.67)$ \\
$\mathrm{MgO}$ & $38.27(1.67)$ & $40.87(2.97)$ & $39.38(0.79)$ \\
$\mathrm{CaO}$ & $2.40(0.59)$ & $2.09(0.79)$ & $2.73(0.52)$ \\
$\mathrm{Na}_{2} \mathrm{O}$ & $0.12(0.14)$ & $0.06(0.06)$ & $0.05(0.06)$ \\
$\mathrm{CO}_{2}$ & $50.75(1.31)$ & $51.04(0.74)$ & $51.33(1.11)$ \\
$\mathrm{Total}$ & $100.68(2.59)$ & $101.12(1.07)$ & $100.85(2.88)$ \\
$\mathrm{Fe}{ }^{2+}$ & $0.110(0.008)$ & $0.085(0.039)$ & $0.087(0.006)$ \\
$\mathrm{Mg}$ & $0.823(0.024)$ & $0.874(0.053)$ & $0.838(0.032)$ \\
$\mathrm{Ca}$ & $0.037(0.008)$ & $0.032(0.013)$ & $0.042(0.007)$ \\
$\mathrm{Na}$ & $0.003(0.004)$ & $0.002(0.002)$ & $0.002(0.002)$ \\
$\mathrm{C}$ & $1.000(0.000)$ & $1.000(0.000)$ & $1.000(0.000)$ \\
\hline
\end{tabular}

possible topologies arising from the complexity in the shape of the solvus for ternary carbonates are better displayed.

At low temperature (below $700{ }^{\circ} \mathrm{C}$, Fig. 8a), the extent of solution between magnesite-siderite and dolomiteankerite series is very limited. At low $\mathrm{X}_{\mathrm{Mg}}$, the phase diagram is characterized by the three-carbonate assemblage siderite-dolomite-aragonite. The phase diagram therefore accounts for the occurrence of dolomite and dolomite + magnesite in experiments on mafic compositions (this study, and Poli et al., 2009) in lawsonitebearing eclogites. Between 700 and $900{ }^{\circ} \mathrm{C}$, the one phase field for dolomite-ankerite-Mg-calcite solid solution largely expands.

The key observation in all experiments at $900{ }^{\circ} \mathrm{C}$ is the occurrence of two carbonate solids, aragonite, and dolomite in forward experiment SPT5, and aragonite and $(\mathrm{Mg}, \mathrm{Fe})$-calcite in sandwich experiment SPT8, coexisting with the hydrous carbonatitic liquid. In this temperature region, phase relationships in the ternary region dolomite-ankerite-aragonite are complex. The solvus of carbonates with R-3C structure resembles that of feldspar, i.e., with large immiscibility field along only one of the three binaries, namely $\mathrm{CaCO}_{3}-\mathrm{CaMg}\left(\mathrm{CO}_{3}\right)_{2}$; such immiscibility coupled to the stability of aragonite over pure calcite at high pressure leads to the possible occurrence of three carbonates at $870{ }^{\circ} \mathrm{C}$ (Fig. 8b) and high $\mathrm{X}_{\mathrm{Mg}}$, i.e., aragonite $+\mathrm{Mg}$-calcite + dolomite. The composition of the hydrous carbonatitic liquids obtained at $900{ }^{\circ} \mathrm{C}$, both for forward and sandwich geometries, projects in the upper portion of this compositional space, close to the Mg-calcite composition expected to be in equilibrium with aragonite and dolomite (compare Fig. 8c and $8 \mathrm{~b}$ ). Again, the phase diagram recalls that of ternary feldspar. As long as two carbonates coexist with the melt, 
Table 7 Chemical composition of (Mg,Fe)-calcite. Units are weight percent of oxides and atoms per formula unit

\begin{tabular}{|c|c|c|c|c|c|}
\hline Run & SPT3 & FB6 & SPT7 & SPT8 & SPT10 \\
\hline$P(\mathrm{GPa})$ & 3.8 & 4.0 & 3.8 & 4.2 & 4.2 \\
\hline$T\left({ }^{\circ} \mathrm{C}\right)$ & 1000 & 870 & 900 & 900 & 900 \\
\hline $\mathrm{FeO}$ & $2.40(0.41)$ & $2.77(0.87)$ & $2.34(0.17)$ & $2.69(0.17)$ & $3.42(0.37)$ \\
\hline $\mathrm{MgO}$ & $13.92(0.36)$ & $6.61(1.29)$ & $5.64(0.53)$ & $8.39(0.45)$ & $10.40(0.50)$ \\
\hline $\mathrm{CaO}$ & $37.07(0.74)$ & $45.47(2.49)$ & $47.18(0.85)$ & $42.90(1.45)$ & $40.86(1.26)$ \\
\hline $\mathrm{Na}_{2} \mathrm{O}$ & $0.07(0.05)$ & $0.06(0.02)$ & $0.06(0.02)$ & $0.07(0.06)$ & $0.03(0.02)$ \\
\hline $\mathrm{CO}_{2}$ & $45.98(0.70)$ & $44.92(2.83)$ & $44.97(0.64)$ & $44.95(0.37)$ & $45.69(0.83)$ \\
\hline Total & $99.44(1.51)$ & $99.82(2.32)$ & $100.18(1.39)$ & $99.01(0.93)$ & $100.39(1.84)$ \\
\hline $\mathrm{Fe}^{2+}$ & $0.064(0.010)$ & $0.075(0.021)$ & $0.064(0.004)$ & $0.073(0.004)$ & $0.092(0.010)$ \\
\hline $\mathrm{Mg}$ & $0.661(0.011)$ & $0.321(0.054)$ & $0.274(0.023)$ & $0.408(0.022)$ & $0.497(0.022)$ \\
\hline $\mathrm{Ca}$ & $1.266(0.023)$ & $1.590(0.052)$ & $1.647(0.026)$ & $1.498(0.040)$ & $1.403(0.025)$ \\
\hline $\mathrm{Na}$ & $0.004(0.003)$ & $0.004(0.001)$ & $0.004(0.001)$ & $0.004(0.004)$ & $0.002(0.001)$ \\
\hline$C$ & $2.000(0.000)$ & $2.000(0.000)$ & $2.000(0.000)$ & $2.000(0.000)$ & $2.000(0.000)$ \\
\hline
\end{tabular}

the liquidus surface has to form a univariant line descending toward Fe-rich compositions. However, when the solidus assemblage in equilibrium with the liquid line of descent leaves the solvus, this univariant reaction degenerates to a minimum valley in the liquidus surface (schematically when the line becomes dashed in Fig. 8c), as in feldspars close to the albite-K-feldspar binary (see Figure 10.28 in Philpotts and Ague, 2009).

Table 8 Chemical composition of solids precipitated on quenching experiments. Units are weight percent of oxides and atoms per formula unit for carbonate. CIPW norm is given for silicate glass

\begin{tabular}{|c|c|c|c|c|}
\hline \multirow[b]{2}{*}{ Run } & \multicolumn{2}{|c|}{ Quench carbonate } & \multirow[b]{2}{*}{ Run } & \multirow{2}{*}{$\begin{array}{l}\text { Silicate glass } \\
\text { SPT8 }\end{array}$} \\
\hline & SPT5 & SPT8 & & \\
\hline$P(\mathrm{GPa})$ & 4.2 & 4.2 & $P(\mathrm{GPa})$ & 4.2 \\
\hline$T\left({ }^{\circ} \mathrm{C}\right)$ & 900 & 900 & $T\left({ }^{\circ} \mathrm{C}\right)$ & 900 \\
\hline $\mathrm{SiO}_{2}$ & $1.79(0.70)$ & $1.79(1.81)$ & $\mathrm{SiO}_{2}$ & $65.89(3.32)$ \\
\hline $\mathrm{Al}_{2} \mathrm{O}_{3}$ & $1.41(0.18)$ & $0.38(0.21)$ & $\mathrm{Al}_{2} \mathrm{O}_{3}$ & $12.22(1.68)$ \\
\hline $\mathrm{FeO}$ & $5.38(0.39)$ & $4.22(0.43)$ & $\mathrm{FeO}$ & $0.60(0.77)$ \\
\hline $\mathrm{MgO}$ & $3.76(0.26)$ & $6.53(0.35)$ & $\mathrm{MgO}$ & $0.41(0.04)$ \\
\hline $\mathrm{CaO}$ & $40.16(0.85)$ & $40.22(1.43)$ & $\mathrm{CaO}$ & $2.85(0.65)$ \\
\hline $\mathrm{Na}_{2} \mathrm{O}$ & $2.26(0.07)$ & $2.27(1.23)$ & $\mathrm{Na}_{2} \mathrm{O}$ & $2.31(1.90)$ \\
\hline $\mathrm{CO}_{2}$ & $44.68(0.43)$ & $46.25(1.08)$ & - & \\
\hline Total & 99.42 & 101.66 & Total & $84.28(3.87)$ \\
\hline $\mathrm{Si}$ & $0.06(0.02)$ & $0.06(0.06)$ & Q & 51.38 \\
\hline $\mathrm{Al}$ & $0.05(0.01)$ & $0.01(0.01)$ & $a b$ & 25.19 \\
\hline $\mathrm{Fe}^{2+}$ & $0.15(0.01)$ & $0.11(0.01)$ & an & 17.17 \\
\hline $\mathrm{Mg}$ & $0.18(0.01)$ & $0.31(0.02)$ & cor & 4.28 \\
\hline $\mathrm{Ca}$ & $1.41(0.04)$ & $1.36(0.02)$ & hy & 1.38 \\
\hline $\mathrm{Na}$ & $0.14(0.01)$ & $0.14(0.07)$ & $\mathrm{mt}$ & 0.08 \\
\hline C & $2.00(0.00)$ & $2.00(0.00)$ & hem & 0.52 \\
\hline
\end{tabular}

Whether this univariant melting reaction has the topology of co-precipitation (cotectic), or a reversal to resorptional (peritectic) occurs with decreasing $\mathrm{X}_{\mathrm{Mg}}$, it is at present impossible to ascertain.

The composition of hydrous carbonatitic liquids found here closely approach those measured by Hammouda (2003) in a study on high-pressure melting of a carbonated eclogite, at $6.5-10 \mathrm{GPa}, 1000{ }^{\circ} \mathrm{C}$. At lower pressure, 3.5-5 GPa, similar results were obtained by Kiseeva et al. (2012) at $1100{ }^{\circ} \mathrm{C}$. Starting materials of both experimental studies were characterized by the presence of minor $\mathrm{H}_{2} \mathrm{O}, 0.12$ wt.\% in Hammouda (2003), 0.5 wt.\% in Kiseeva et al. (2012). Again, a common feature of their syntheses and the results presented here is the crystallization of aragonite or Mg-calcite (83-92 mol\% $\mathrm{CaCO}_{3}$ in Kiseeva et al. 2012) with the carbonatitic liquid. Because of the differences in bulk compositions (Table 1), and pressure and temperature conditions, $\mathrm{H}_{2} \mathrm{O}$ is expected to play a fundamental role in modifying the liquids surface of these carbonatitic liquids, as observed in silicate systems.

Anhydrous experiments on carbonated eclogites (Dasgupta et al., 2004; Dasgupta et al. 2005, Yaxley and Brey 2004) produced carbonatitic liquids with a much lower $\mathrm{Ca} /(\mathrm{Ca}+\mathrm{Mg}+\mathrm{Fe})$ in equilibrium with dolomite-Mg-calcite solid solution approximately at 60-70 mol\% $\mathrm{CaCO}_{3}$ (Yaxley and Brey 2004) or magnesite (Dasgupta et al. 2004, above 4.1 GPa). These liquid compositions therefore schematically approach the minimum on the anhydrous liquidus surface as constrained by the end-member binary system $\mathrm{MgCO}_{3}-\mathrm{CaCO}_{3}$ (Irving and Wyllie 1975; Byrnes and Wyllie 1981), neglecting for simplicity the influence of iron and alkali in lowering the absolute temperature of melting (Dasgupta et al., 2005). Above $1100{ }^{\circ} \mathrm{C}$ (Fig. 8d), complete 

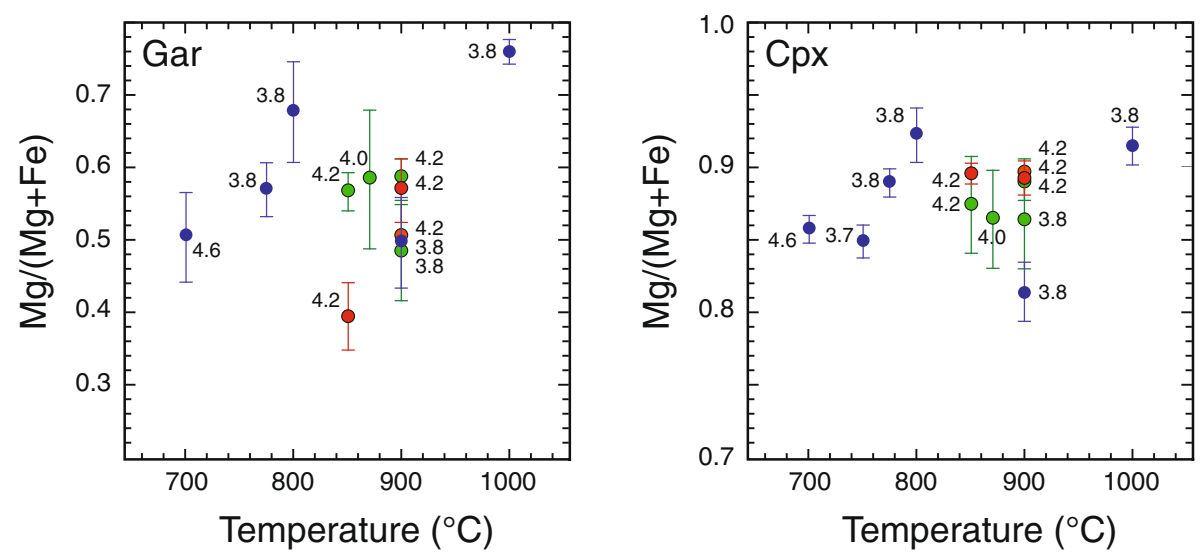

Fig. $7 \mathrm{Mg} /(\mathrm{Mg}+\mathrm{Fe})$ variations in garnet and clinopyroxene with temperature. Blue dots, forward experiments, bulk 593; green, forward experiments, bulk 593ccb; red, sandwich experiments
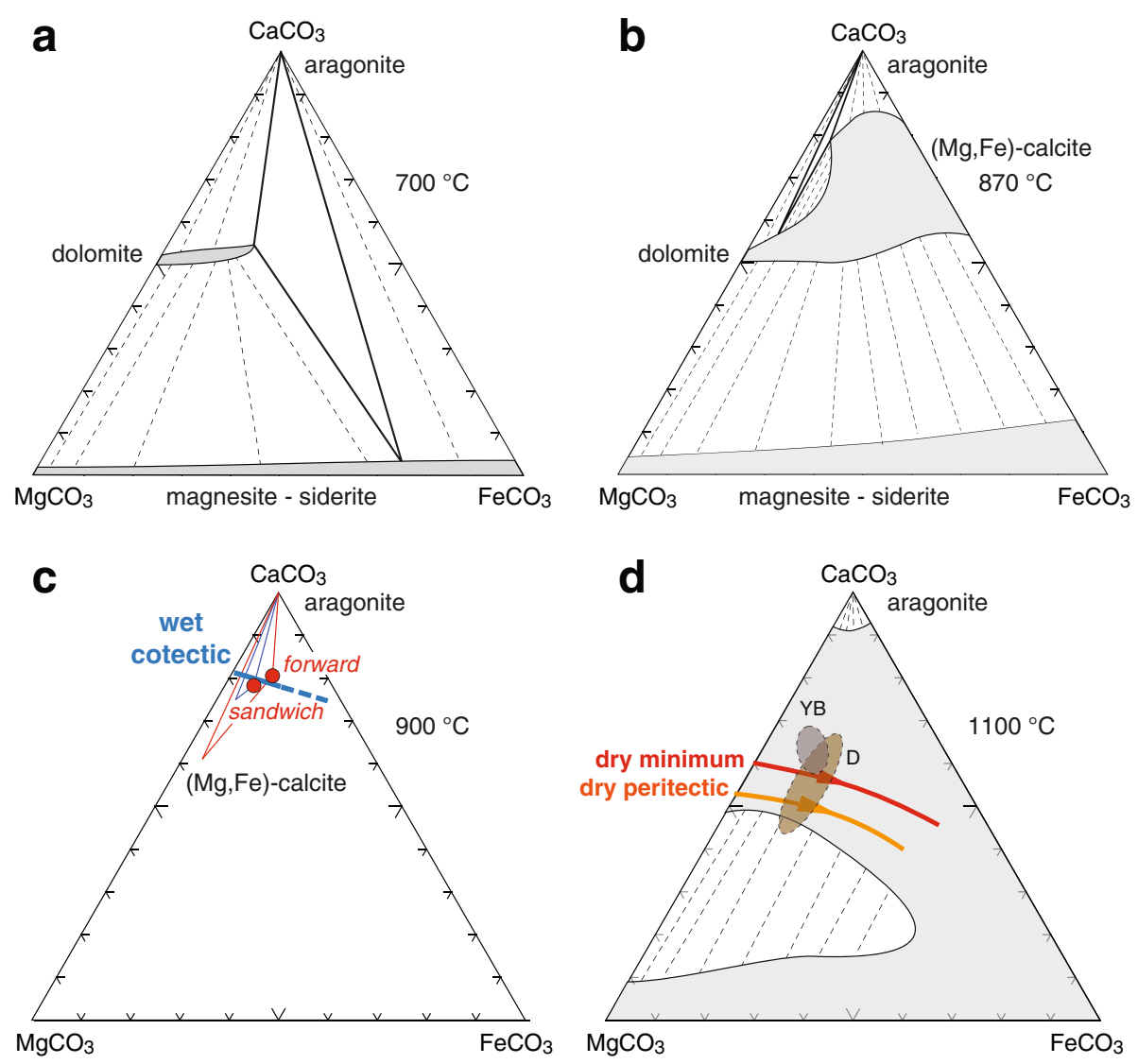

Fig. 8 Phase diagrams for ternary carbonates. $\mathbf{a}$ and $\mathbf{b}$ calculated phase diagram at 700 and $870{ }^{\circ} \mathrm{C}$, respectively; $\mathbf{c}$ experimentally derived phase assemblages at $900{ }^{\circ} \mathrm{C}$ and schematic arrangement of a wet cotectic line based on the composition of liquids (red circles) retrieved from forward and sandwich experiments; $\mathbf{d}$ calculated high-temperature phase diagram compared with the composition of liquids from anhydrous experiments (D, Dasgupta et al. 2004, 2005; YB, Yaxley and Brey 2004) 
miscibility occurs in the field dolomite-ankerite-calcite; therefore, a single $\mathrm{Ca}$-carbonate (eventually with addition of minor magnesite) is expected with the liquid. At higher pressures, $P>9 \mathrm{GPa}$, Kiseeva et al. (2013) found that the anhydrous carbonatitic solidus is located at approximately $1300{ }^{\circ} \mathrm{C}$. Liquids produced coexist with fully decarbonated residues, and their composition therefore reflect the relatively high $\mathrm{Ca} /(\mathrm{Ca}+\mathrm{Mg}+\mathrm{Fe})$ of the starting material, compared to previous studies (Dasgupta et al., 2004; Dasgupta et al. 2005, Yaxley and Brey 2004).

$\mathrm{H}_{2} \mathrm{O}$ was found to cause a dramatic lowering of the liquidus surface for $\mathrm{CaCO}_{3}$ (Wyllie and Boettcher, 1969), and for $\mathrm{CaCO}_{3}+\mathrm{SiO}_{2}$ (Boettcher and Wyllie 1969; Huang et al., 1980). At $3 \mathrm{GPa}$, calcite melting occurs at $1600{ }^{\circ} \mathrm{C}$ (Irving and Wyllie, 1975), whereas addition of excess $\mathrm{H}_{2} \mathrm{O}$ leads to the formation of a eutectic at $530-540{ }^{\circ} \mathrm{C}$, with calcite, portlandite, and an aqueous fluid on the solidus. Similarly, vaporabsent melting of calcite + quartz at $3 \mathrm{GPa}$ was found at $1480{ }^{\circ} \mathrm{C}$ (Huang et al., 1980) and wet melting at $530{ }^{\circ} \mathrm{C}$ (Boettcher and Wyllie 1969). Notably, the influence of $\mathrm{H}_{2} \mathrm{O}$ on the melting of magnesite is not as pronounced, eutectic melting at $3 \mathrm{GPa}$ given by magnesite + periclase + vapor $=$ liquid at approximately $1400{ }^{\circ} \mathrm{C}$, and above $5 \mathrm{GPa}$, by magnesite + brucite + vapor $=$ liquid at $1150{ }^{\circ} \mathrm{C}$ (Ellis and Wyllie, 1979). This asymmetry in the response of $\mathrm{CaCO}_{3}$-rich liquids to the addition of $\mathrm{H}_{2} \mathrm{O}$ compared to $\mathrm{MgCO}_{3}$-rich liquids should therefore cause a progressive compositional shift of the minimum of the liquidus surface toward $\mathrm{CaCO}_{3}$.

\section{The solidus for carbonated epidote eclogites}

The composition of the putative single liquid generated in experiments at $4.2 \mathrm{GPa}, 900{ }^{\circ} \mathrm{C}$, precipitating $(\mathrm{Mg}, \mathrm{Fe})$-calcite dendrites intermingled with tonalitic glass, reveal the importance of both carbonates and Al-rich silicates on the solidus for carbonated eclogites. The stoichiometry of reactions accounting for melting can be described in the model system $\mathrm{CaO}$ $\mathrm{MgO}-\mathrm{Al}_{2} \mathrm{O}_{3}-\mathrm{SiO}_{2}-\mathrm{H}_{2} \mathrm{O}-\mathrm{CO}_{2}$ (CMASHC) (Fig. 9a), assuming, for simplicity, that the $\mathrm{CO}_{2}$ content of the liquid balances $\mathrm{Ca}$ and $\mathrm{Mg}$, and that $\mathrm{H}_{2} \mathrm{O}$ content is arbitrarily set to $1 / 3$ of that of $\mathrm{CO}_{2}$. The latter assumption simply affects the stoichiometric coefficient of "vapor" $\left(\mathrm{H}_{2} \mathrm{O}\right.$ in the present exercise) in the reaction set. The liquid composition is given by 0.30 $\mathrm{CaO}, 0.10 \mathrm{MgO}, 0.05 \mathrm{SiO}_{2}, 0.01 \mathrm{Al}_{2} \mathrm{O}_{3}, 0.14 \mathrm{H}_{2} \mathrm{O}$, and $0.40 \mathrm{CO}_{2}$.

The subsolidus breakdown of epidote is given by the reaction (in parentheses, the phase is absent, following Schreinemakers' convention).

$$
\begin{aligned}
6 \text { zoisite }+6 \text { dolomite }= & 12 \text { aragonite } \\
& +4 \text { garnet }(\text { gr50 }) \\
& +2 \text { kyanite }+4 \text { coesite } \\
& +3 \text { vapor }(\text { liq }) .
\end{aligned}
$$

Eutectic melting is defined by the degenerate reaction:

$$
\begin{aligned}
1 \text { kyanite } & +4 \text { coesite }+10 \text { dolomite }+20 \text { aragonite } \\
& +14 \text { vapor }=100 \text { liquid }(\mathrm{zo}, \mathrm{gr}) .
\end{aligned}
$$

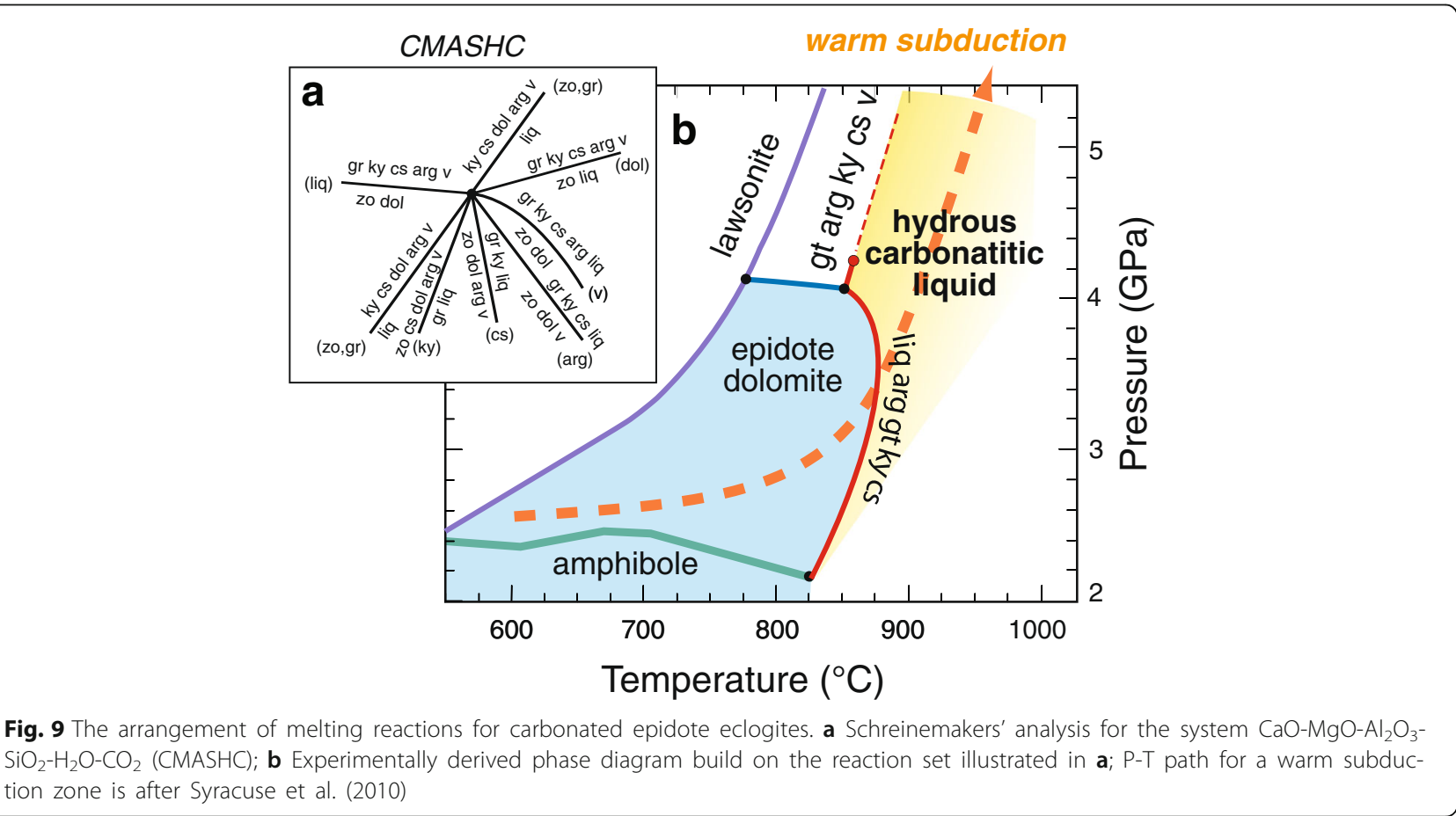


The wet melting for carbonated zoisite-bearing eclogites can be represented by the following reaction:

$$
\begin{aligned}
6 \text { zoisite } & +4 \text { coesite }+26 \text { dolomite }+28 \text { aragonite } \\
& +25 \text { vapor }=4 \text { garnet }+200 \text { liquid }(\mathrm{ky}) .
\end{aligned}
$$

The most relevant reaction accounting for the generation of melt is the "vapor-absent" reaction:

$$
\begin{aligned}
84 \text { zoisite } & +114 \text { dolomite }=56 \text { garnet }+25 \text { kyanite } \\
& +44 \text { coesite }+108 \text { aragonite }+300 \text { liquid }(v),
\end{aligned}
$$

accounting for melting observed in experiment SPT 8 at $4.2 \mathrm{GPa}, 900{ }^{\circ} \mathrm{C}$.

The Schreinemakers' analysis of the four reactions above, and of the additional four reactions defined in the six-component system CMASHC, can be build on the model reactions in the system $\mathrm{CASH}$, controlling the phase relationships of zoisite at high pressure and high temperature (Schmidt and Poli, 2004). Figure 9a shows the schematic arrangement of these reactions in pressure and temperature space. The pseudo-invariant point for the compositional pseudo-section of gabbroic eclogite investigated here is located at approximately $4 \mathrm{GPa}$, $870-900{ }^{\circ} \mathrm{C}$, and the temperature range between eutectic reaction (zo, gar) and vapor-absent reaction $(v)$ is expected to be very limited, given the location of eutectic melting in CASH given by reaction (2) (Fig. 5).

The minimum temperatures found for carbonatitic liquids in a variety of mafic bulk compositions range from 1020-1080 ${ }^{\circ} \mathrm{C}, 3-5 \mathrm{GPa}$, in anhydrous carbonated MORB eclogites (Dasgupta et al. 2004), $1180-300{ }^{\circ} \mathrm{C}$ at 3-4 GPa in a silica-poor carbonated eclogite (Yaxley and Brey 2004), $1100{ }^{\circ} \mathrm{C}$ at $3-5 \mathrm{GPa}$ in Kiseeva et al. (2012), and $1000{ }^{\circ} \mathrm{C}$ at $6.5-10 \mathrm{GPa}$ in Hammouda (2003). The latter two studies contain $\mathrm{H}_{2} \mathrm{O}$ in the starting material and its effect on the composition of the liquids has been discussed above. In carbonated pelites (i.e., $\mathrm{H}_{2} \mathrm{O}$-bearing), carbonatitic melts have been found to exsolve from the silicate liquid above $1100{ }^{\circ} \mathrm{C}$ at 3-5 GPa (Thomsen and Schmidt 2008; Skora et al., 2015). Hydrated, carbonated peridotites again show carbonatites on the solidus at $1070{ }^{\circ} \mathrm{C}$ at 2-3 GPa (Tumiati et al. 2013). All of these bulk compositions are characterized by a $\mathrm{Ca} /(\mathrm{Ca}+\mathrm{Mg}+\mathrm{Fe})$ ratio lower than 0.5 ; therefore, the $>150{ }^{\circ} \mathrm{C}$ difference between minimum temperatures found here and previous studies should be ascribed primarily to the combined effect of $\mathrm{H}_{2} \mathrm{O}$ and high $\mathrm{Ca} /(\mathrm{Ca}+\mathrm{Mg}+\mathrm{Fe})$ values, promoting discrete amounts of eutectic carbonatitic liquids.

\section{Conclusions}

Altered cumulate gabbros represent kilometer-thick portions of the subducted oceanic crust. Hydration and carbonation occur not only in ocean floor metamorphism, but they are also expected to further progress at depth at the trench-rise system in response to bending-related fracturing and faulting of the subducting lithosphere (Faccenda 2014). Plagioclase-rich rocks should be therefore regarded as volatile reservoirs as important as the altered oceanic basalts or the overlying sedimentary cover, which is often limited to a few hundreds meters in thickness (Whittaker et al. 2013).

$\mathrm{CO}_{2}$ and $\mathrm{H}_{2} \mathrm{O}$ are recycled back into the mantle mostly by carbonates (the role of graphite is neglected here) and by hydrous minerals, of which epidote is the most important in mafic bulk compositions for thermal regimes exceeding lawsonite stability. The stability field of epidote is maximized in mafic bulk compositions originally enriched in anorthitic plagioclase, and reaches 3.8-4 GPa in phase relations presented here. Epidote, dolomite, and kyanite occur on the solidus of mafic eclogites in a large pressure range. Calculated pressuretemperature paths for the subducted slab in relatively warm subduction zones (Fig. 9b; see also Figure 6 in Syracuse et al., 2010) suggest that the altered gabbroic rocks of the oceanic crust may undergo partial melting at sub-arc depth. Liquids generated at $870-900{ }^{\circ} \mathrm{C}$ are hydrous, with both carbonatitic and silicate components, whose proportions are a function of the $\mathrm{H}_{2} \mathrm{O}$ available. $\mathrm{H}_{2} \mathrm{O}$ component can be provided internally by epidote breakdown similarly to mica fluid-absent melting reactions, or by an external source, even beyond epidote stability field, assuming that the oceanic crust is flushed by aqueous fluids derived from the deserpentinization of the underlying harzburgitic rocks. Such liquids should be more common if actual temperatures in subduction zones are higher than previously expected from numerical modeling (Penniston-Dorland et al. 2015).

Thermodynamic reconstruction of the phase diagram for ternary, $\mathrm{Ca}-\mathrm{Mg}-\mathrm{Fe}$ carbonates, along the hydrous carbonatitic solidus discussed here, reveals that two carbonates, dolomite and aragonite/Mg-calcite, can coexist on the liquidus surface. As a result, at such relatively low temperatures a Ca-rich carbonate is expected to be a common product of eclogite melting, for a wide range of starting bulk compositions. The stability of a Ca-rich carbonate over the first melting interval for carbonatitic liquids should therefore affect the fractionation paths of both liquids and residues on segregation processes.

Carbonatitic liquids, enriched in $\mathrm{Ca}, \mathrm{Si}$, volatiles, and secondarily $\mathrm{Al}$, migrate in the mantle wedge, react with olivine, and produce clinopyroxene and magnesite, therefore fixing $\mathrm{CO}_{2}$ back again temporarily in the mineral assemblage. If excess $\mathrm{H}_{2} \mathrm{O}$ does not fractionate from the precipitated carbonate, then the downgoing flow in the hanging wall of the slab drags these carbonated pyroxenites above $950-1050{ }^{\circ} \mathrm{C}$ isotherm where the hydrous carbonated ultramafics melt (Wallace and Green 1988, Tumiati et al 2013), therefore generating a derivate 
hydrous carbonatitic liquid of dolomitic composition. It is highly unlikely that such liquids reach shallow levels to give carbonatitic rocks; they are rather expected to progressively dilute in the primary arc melts and to provide a "pyroxenitic" geochemical signature for the source region of arc magmas.

\section{Abbreviations}

AMP: Amphibole; AN: Anorthite; ARG: Aragonite; CARB: Carbonate/ carbonatitic; CC: Calcite; COE: Coesite; COR: Corundum; CPX: Clinopyroxene; GR: Grossular; GT: Garnet; KY: Kyanite; LIQ: Liquid; MG-CC: Mg-calcite; MGS: Magnesite; Q: Quartz; Sil: Silicate; V: Vapor; ZO: Zoisite

\section{Acknowledgements}

Reviews by two anonymous referees significantly improved the manuscript.

\section{Funding}

This research was supported by the Italian Ministry of Education, University and Research (MIUR) program PRIN2012R33ECR. S.P. acknowledges support from the Deep Carbon Observatory (DCO).

\section{Competing interest}

The author declares that he has no competing interests.

Received: 23 November 2015 Accepted: 24 August 2016

Published online: 23 September 2016

\section{References}

Alt JC, Emmermann R (1985) Geochemistry of hydrothermally altered basalts: Deep Sea Drilling Project hole 504B, Leg 83. In Rep DSDP 83:249-262

Alt JC, Teagle DAH (1999) The uptake of carbon during alteration of ocean crust. Geochim Cosmochim Acta 63:1527-1535

Bach W, Alt JC, Niu YL, Humphris SE, Erzinger J, Dick HJB (2001) The geochemical consequences of late-stage low-grade alteration of lower ocean crust at the SW Indian Ridge: results from ODP hole 735B (Leg 176). Geochim Cosmochim Acta 65:3267-3287

Boettcher AL (1970) The system $\mathrm{CaO}-\mathrm{Al}_{2} \mathrm{O}_{3}-\mathrm{SiO}_{2}-\mathrm{H}_{2} \mathrm{O}$ at high pressures and temperatures. J Petrol 11:337-379

Boettcher AL, Wyllie PJ (1969) The system $\mathrm{CaO}-\mathrm{SiO}_{2}-\mathrm{CO}_{2}-\mathrm{H}_{2} \mathrm{O}$ - III. Second critical end-point on the melting curve. Geochim Cosmochim Acta 33:611-632

Bucher K, Grapes R (2009) The eclogite-facies Allalin gabbro of the Zermatt-Saas Ophiolite, Western Alps: a record of subduction zone hydration. J Petrol 50: $1405-1442$

Byrnes AP, Wyllie PJ (1981) Subsolidus and melting relations for the join $\mathrm{CaCO}_{3}$ $\mathrm{MgCO}_{3}$ at 10 kbars. Geochim Cosmochim Acta 45:321-328

Connolly JAD (1990) Multivariable phase diagrams: an algorithm based on generalized thermodynamics. Am J Sci 290:666-718

Connolly JAD (2005) Computation of phase equilibria by linear programming: a tool for geodynamic modelling and its application to subduction zone decarbonation. Earth Planet Sci Lett 236:524-541

Dasgupta R, Hirschmann MM, Withers AC (2004) Deep global cycling of carbon constrained by the solidus of anhydrous, carbonated eclogite under upper mantle conditions. Earth Planet Sci Lett 227:73-85

Dasqupta R, Hirschmann MM, Dellas N (2005) The effect of bulk composition on the solidus of carbonated eclogite from partial melting experiments at 3 GPa. Contrib Mineral Petrol 149:288-305

Ellis DE, Wyllie PJ (1979) Carbonation, hydration, and melting relations in the system $\mathrm{MgO}-\mathrm{H}_{2} \mathrm{O}-\mathrm{CO}_{2}$ at pressures up to $100 \mathrm{kbar}$. Am Mineral 64:32-40

Faccenda M (2014) Water in the slab: a trilogy. Tectonophysics 614:1-30

Forneris JF, Holloway JR (2003) Phase equilibria in subducting basaltic crust: implications for $\mathrm{H}_{2} \mathrm{O}$ release from the slab. Earth Planet Sci Lett 214:187-201

Franzolin E, Schmidt MW, Poli S (2011) Ternary Ca-Fe-Mg carbonates: subsolidus phase relations at $3.5 \mathrm{GPa}$ and a thermodynamic solid solution model including order/disorder. Contrib Mineral Petrol 161:213-227

Fumagalli P, Poli S (2005). Experimentally determined phase relations in hydrous peridotites to $6.5 \mathrm{GPa}$ and their consequences on the dynamics of subduction zones. Journal of Petrology 46:555-578.

Godard M, Awaji S, Hansen H, Hellebrand E, Brunelli D, Johnson K, Yamasaki T, Maeda J, Abratis M, Christie D, Kato Y, Mariet C, Rosner M (2009) Geochemistry of a long in situ section of intrusive slow-spread oceanic lithosphere: results from IODP site U1309 (Atlantis Massif, 30N Mid-AtlanticRidge). Earth Planet Sci Lett 279:110-122

Hammouda T (2003) High-pressure melting of carbonated eclogite and experimental constraints on carbon recycling and storage in the mantle. Earth Planet Sci Lett 214:357-368

Hirschmann MM, Dasgupta R (2007) A modified iterative sandwich method for determination of near-solidus partial melt compositions. I. Theoretical considerations. Contrib Mineral Petrol 154:635-645

Holland TJB, Powell R (1998) An internally consistent thermodynamic data set for phases of petrological interest. J Met Geol 16:309-343

Huang W-L, Wyllie PJ, Nehru CE (1980) Subsolidus and liquidus phase relationships in the system $\mathrm{CaO}-\mathrm{SiO}_{2}-\mathrm{CO}_{2}$ to $30 \mathrm{kbar}$ with geological applications. Am Miner 65:285-301

Irving AJ, Wyllie PJ (1975) Subsolidus and melting relationships for calcite, magnesite and the join $\mathrm{CaCO}_{3}-\mathrm{MgCO}_{3}$ to $36 \mathrm{kbar}$. Geochim Cosmochim Acta 39:35-53

Kerrick DM, Connolly JAD (2001) Metamorphic devolatilization of subducted oceanic metabasalts: implications for seismicity, arc magmatism and volatile recycling. Earth Planet Sci Lett 189:19-29

Kessel R, Ulmer P, Pettke T, Schmidt MW, Thompson AB (2005) The water-basalt system at 4 to $6 \mathrm{GPa}$ : phase relations and the second critical endpoint in a K-free eclogite at $700-1400^{\circ} \mathrm{C}$. Earth Planet Sci Lett 237:873-892

Kiseeva ES, Yaxley GM, Hermann J, Litasov KD, Rosenthal A, Kamenetsky VS (2012) An experimental study of carbonated eclogite at 3.5-5. $5 \mathrm{GPa}$-implications for silicate and carbonate metasomatism in the Cratonic mantle. J Pet 53:727-759

Kiseeva ES, Litasov KD, Yaxley GM, Ohtani E, Kamenetsky VS (2013) Melting and phase relations of carbonated eclogite at 9-21 GPa and the petrogenesis of alkali-rich melts in the deep mantle. J Pet 54:1555-1583

Lagabrielle Y, Brovarone AV, Ildefonse B (2015) Fossil oceanic core complexes recognized in the blueschist metaophiolites of Western Alps and Corsica. Earth Sci Rev 141:1-26

Meyer PS, Dick HJB, Thompson G (1989) Cumulate gabbros from the southwest Indian Ridge, $54^{\circ} \mathrm{S}-7^{\circ} 16^{\prime} \mathrm{E}$ : implications for magmatic processes at slow spreading ridge. Contrib Mineral Petrol 103:44-63

Pawley AR, Holloway JR (1993) Water sources for subduction zone volcanism—new experimental constraints. Science 260:664-667

Penniston-Dorland SC, Kohn MJ, Manning CE (2015) The global range of subduction zone thermal structures from exhumed blueschists and eclogites: rocks are hotter than models. Earth Planet Sci Lett 428:243-254

Perk NW, Coogan LA, Karson JA, Klein EM, Hanna HD (2007) Petrology and geochemistry of primitive lower oceanic crust from Pito Deep: implications for the accretion of the lower crust at the Southern East Pacific Rise. Contrib Mineral Petrol 154:575-590

Perugini D, Poli G (2005) Viscous fingering during replenishment of felsic magma chambers by continuous inputs of mafic magmas: field evidence and fluidmechanics experiments. Geology 33:5-8

Philpotts AR, Ague JJ (2009) Principles of igneous and metamorphic petrology. Cambridge University Press, Cambridge

Poli S (2015) Carbon mobilized at shallow depths in subduction zones by carbonatitic liquids. Nat Geo 8:633-636

Poli S, Schmidt MW (1995) $\mathrm{H}_{2} \mathrm{O}$ transport and release in subduction zones-experimental constraints on basaltic and andesitic systems. J Geophys Res 100:22299-22314

Poli S, Schmidt MW (1998) The high-pressure stability of zoisite and phase relationships of zoisite-bearing assemblages. Contrib Mineral Petrol 130:162-175

Poli S, Schmidt MW (2002) Petrology of subducted slabs. Annu Rev Earth Planet Sci 30:207-235

Poli S, Schmidt MW (2004) Experimental subsolidus studies on epidote minerals. Rev Mineral Geochem 56:171-195

Poli S, Franzolin E, Fumagalli P, Crottini A (2009) The transport of carbon and hydrogen in subducted oceanic crust: an experimental study to $5 \mathrm{GPa}$. Earth Planet Sci Lett 278:350-360

Schmidt MW, Poli S (1998) Experimentally based water budgets for dehydrating slabs and consequences for arc magma generation. Earth Planet Sci Lett 163:361-379

Schmidt MW, Poli S (2004) Magmatic epidote. Rev Mineral Geochem 56:399-430

Skora S, Blundy JD, Brooker RA, Green ECR, de Hoog JCM, Connolly JAD (2015) Hydrous phase relations and trace element partitioning behaviour in calcareous sediments at subduction-zone conditions. J Petrol 56:953-980 
Syracuse EM, van Keken PE, Abers GA (2010) The global range of subduction zone thermal models. Phys Earth Planetary Int 183:73-90

Thompson AB, Ellis DJ (1994) $\mathrm{CaO}+\mathrm{MgO}+\mathrm{Al}_{2} \mathrm{O}_{3}+\mathrm{SiO}_{2}+\mathrm{H}_{2} \mathrm{O}$ to $35 \mathrm{kbar}$ : amphibole, talc and zoisite dehydration and melting reactions in the silicaexcess part of the system and their possible significance in subduction zones, amphibolite melting and magma fractionation. Am J Sci 294:1229-1289

Thomsen TB, Schmidt MW (2008) Melting of carbonated pelites at 2.5-5.0 GPa, silicate-carbonatite liquid immiscibility, and potassium-carbon metasomatism of the mantle. Earth Planet Sci Lett 267:17-31

Tumiati S, Fumagalli P, Tiraboschi C, Poli S (2013) An experimental study on $\mathrm{COH}$-bearing peridotite up to $3.2 \mathrm{GPa}$ and implications for crust-mantle recycling. J Petrol 54:453-479

Yaxley GM, Brey GP (2004) Phase relations of carbonate-bearing eclogite assemblages from 2.5 to $5.5 \mathrm{GPa}$ implications for petrogenesis of carbonatites. Contrib Mineral Petrol 146:606-619

Wallace ME, Green DH (1988) An experimental determination of primary carbonatite magma composition. Nature 335:343-345

Whittaker J, Goncharov A, Williams S, Dietmar Müller R, Leitchenkov G (2013) Global sediment thickness dataset updated for the Australian-Antarctic Southern Ocean. Geochem Geophys Geosys. doi:10.1002/ggge.20181

Wittenberg A (1997) Geochemische und isotopengeochemische Untersuchungen an mafischen Gesteinen der kontinentalen Unterkruste und deren Hochdruck-äquivalenten (Grospydite). Universität Hannover, Dissertation

Wittenberg A, Rohnert D, Gesing TM, Holtz F (2003) Zoisite —an effective trace element vehicle at HP metamorphic processes. Geochim Comsochim Acta 67(18):A535

Wyllie PJ, Boettcher AL (1969) Liquidus phase relationships in the system $\mathrm{CaO}-\mathrm{CO}_{2}-\mathrm{H}_{2} \mathrm{O}$ to 40 kilobars pressure with petrological applications. Am J Sci 267-A:489-508

\section{Submit your manuscript to a SpringerOpen ${ }^{\circ}$ journal and benefit from:}

- Convenient online submission

- Rigorous peer review

- Immediate publication on acceptance

- Open access: articles freely available online

- High visibility within the field

- Retaining the copyright to your article

Submit your next manuscript at $\boldsymbol{s p r i n g e r o p e n . c o m ~}$ 